\title{
Enhanced representation of soil NO emissions in the Community Multiscale Air Quality (CMAQ) model version 5.0.2
}

\author{
Quazi Z. Rasool ${ }^{1}$, Rui Zhang ${ }^{1}$, Benjamin Lash ${ }^{1, a}$, Daniel S. Cohan ${ }^{1}$, Ellen J. Cooter ${ }^{2}$, Jesse O. Bash ${ }^{2}$, and \\ Lok N. Lamsal ${ }^{3,4}$ \\ ${ }^{1}$ Department of Civil and Environmental Engineering, Rice University, Houston, TX, USA \\ ${ }^{2}$ Computational Exposure Division, National Exposure Research Laboratory, Office of Research and Development, \\ US Environmental Protection Agency, Research Triangle Park, NC, USA \\ ${ }^{3}$ Goddard Earth Sciences Technology and Research, Universities Space Research Association, Columbia, MD 21046, USA \\ ${ }^{4}$ NASA Goddard Space Flight Center, Greenbelt, MD 20771, USA \\ ${ }^{a}$ now at: School of Natural Sciences, University of California, Merced, CA, USA
}

Correspondence to: Daniel S. Cohan (cohan@ rice.edu)

Received: 16 May 2016 - Published in Geosci. Model Dev. Discuss.: 2 June 2016

Revised: 24 August 2016 - Accepted: 25 August 2016 - Published: 16 September 2016

\begin{abstract}
Modeling of soil nitric oxide (NO) emissions is highly uncertain and may misrepresent its spatial and temporal distribution. This study builds upon a recently introduced parameterization to improve the timing and spatial distribution of soil NO emission estimates in the Community Multiscale Air Quality (CMAQ) model. The parameterization considers soil parameters, meteorology, land use, and mineral nitrogen $(\mathrm{N})$ availability to estimate $\mathrm{NO}$ emissions. We incorporate daily year-specific fertilizer data from the Environmental Policy Integrated Climate (EPIC) agricultural model to replace the annual generic data of the initial parameterization, and use a $12 \mathrm{~km}$ resolution soil biome map over the continental USA. CMAQ modeling for July 2011 shows slight differences in model performance in simulating fine particulate matter and ozone from Interagency Monitoring of Protected Visual Environments (IMPROVE) and Clean Air Status and Trends Network (CASTNET) sites and $\mathrm{NO}_{2}$ columns from Ozone Monitoring Instrument (OMI) satellite retrievals. We also simulate how the change in soil NO emissions scheme affects the expected $\mathrm{O}_{3}$ response to projected emissions reductions.
\end{abstract}

\section{Introduction}

Nitrogen oxides $\left(\mathrm{NO}_{x}=\mathrm{NO}+\mathrm{NO}_{2}\right)$ play a crucial role in tropospheric chemistry. Availability of $\mathrm{NO}_{x}$ influences the oxidizing capacity of the troposphere as $\mathrm{NO}_{x}$ directly reacts with hydroxyl radicals $(\mathrm{OH})$ and catalyzes tropospheric ozone $\left(\mathrm{O}_{3}\right)$ production and destruction (Seinfeld and Pandis, 2016). $\mathrm{NO}_{x}$ also affects the lifetime of reactive greenhouse gases like $\mathrm{CH}_{4}$ by influencing its dominant oxidant $\mathrm{OH}$ (Steinkamp and Lawrence, 2011), thus affecting the Earth's radiative balance (IPCC, 2007). $\mathrm{NO}_{x}$ also influences rates of formation of inorganic particulate matter (PM) (Wang et al., 2013) and organic PM (Seinfeld and Pandis, 2016).

Soil $\mathrm{NO}_{x}$ emissions accounts for $\sim 15-40 \%$ of the tropospheric $\mathrm{NO}_{2}$ column over the continental United States (CONUS), and up to $80 \%$ in highly $\mathrm{N}$ fertilized rural areas like the Sahel of Africa (Hudman et al., 2012). The estimated amount of nitric oxide (NO) emitted from soils is highly uncertain, ranging from 4 to $15 \mathrm{Tg} \mathrm{Nyr}^{-1}$, with different estimates of total global $\mathrm{NO}_{x}$ budget also showing a mean difference of 60-70\% (Potter et al., 1996; Davidson and Kingerlee, 1997; Yienger and Levy, 1995; Jaeglé et al., 2005; Stavrakou et al., 2008; Steinkamp and Lawrence, 2011; Miyazaki et al., 2012; Stavrakou et al., 2013; Vinken et al., 2014). Soil $\mathrm{NO}_{x}$ is mainly emitted as NO through both microbial activity (biotic/enzymatic) and chemical (abiotic/non-enzymatic) pathways, with emission rates 
varying as a function of meteorological conditions, physicochemical soil properties, and nitrogen $(\mathrm{N})$ inputs from deposition and fertilizer or manure application (Pilegaard, 2013; Hudman et al., 2012). The fraction of soil N emitted as NO varies with meteorological and soil conditions such as temperature, soil moisture content, and $\mathrm{pH}$ (Ludwig et al., 2001; Parton et al., 2001; van Dijk et al., 2002; Stehfest and Bouwman, 2006).

Different biome types, comprised of vegetation and soil assemblages exhibit different $\mathrm{NO}$ emission factors under different soil conditions and climate zones. One of the early attempts to stratify soil NO based on different biomes by Davidson and Kingerlee (1997) involved compiling over 60 articles and 100 field estimates. They clearly identified biomes associated with low $\mathrm{NO}$ emissions like swamps, tundra, and temperate forests, and those with high soil NO fluxes like tropical savanna/woodland and cultivated agriculture. For instance, high soil NO fluxes were observed in croplands, savannahs, or woodlands, N-rich temperate forests, and even boreal/tropical forests with low $\mathrm{NO}_{2}^{-}$availability in warm conditions and acidic soil (Kesik et al., 2006; Cheng et al., 2007; Su et al., 2011). This approach, however, fails to capture within-biome variation in NO emissions (Miyazaki et al., 2012; Vinken et al., 2014). For example, mature forests give higher soil NO flux than rehabilitated and disturbed ones due to higher initial soil N (Zhang et al., 2008). Steinkamp and Lawrence (2011) more recently compiled worldwide emission factors from a data set consisting of 112 articles with 583 field measurements of soil $\mathrm{NO}_{x}$ covering the period from 1976 to 2010, and regrouped them into 24 soil biome types based on a MODIS land cover category as well as Köppen climate zone classifications (Kottek et al., 2006).

Both wet and dry deposition act as sources of nitrogen to soils (Yienger and Levy, 1995; Hudman et al., 2012). N is deposited in both oxidized (e.g., nitrate) and reduced (e.g., ammonium) forms, with ammonium representing a growing share of $\mathrm{N}$ deposition in the USA as anthropogenic $\mathrm{NO}_{x}$ emissions are controlled (Li et al., 2016).

Fertilizer (organic and inorganic) application represent controllable influences on soil $\mathrm{N}$ emissions (Pilegaard, 2013) and are leading sources of reactive $\mathrm{N}$ worldwide (Galloway and Cowling, 2002). US fertilizer use increased by nearly a factor of 4 from 1961 to 1999 (IFIA, 2001). Soil NO emissions increase with rising fertilizer application, with conversion rate of applied fertilizer $\mathrm{N}$ to $\mathrm{NO}_{x}$ being up to $\sim 11 \%$ (Williams et al., 1988; Shepherd et al., 1991). Open and closed chamber studies have shown increasing fertilizer application to increase both $\mathrm{NO}$ and $\mathrm{N}_{2} \mathrm{O}$ fluxes simultaneously, but with variability in the $\mathrm{NO} / \mathrm{N}_{2} \mathrm{O}$ emission ratio (Harrison et al., 1995; Conrad, 1996; Veldkamp and Keller, 1997).

Meteorological conditions influence soil NO emission rates. Soil NO pulsing events occur when water stressed nitrifying bacteria, which remain dormant during dry periods, are activated by the first rains and start metabolizing accumu- lated $\mathrm{N}$ in the soil. Large pulses of biogenic $\mathrm{NO}$ emissions of up to 10-100 times background levels often follow the onset of rain after a dry period and can last for 1-2 days (Davidson, 1992; Yienger and Levy, 1995; Scholes et al., 1997; Jaeglé et al., 2004; Hudman et al., 2010, 2012; Zörner et al., 2016).

Adsorption onto plant canopy surfaces can reduce the amount of soil NO emissions entering the broader atmosphere. The Yienger and Levy (1995) (YL) soil NO scheme followed a canopy reduction factor (CRF) approach (Wang et al., 1998) to account for the reduction of soil NO emission flux via stomatal or cuticle exchange as a function of dry deposition within the canopy on a global scale.

Contemporary air quality models such as the Community Multiscale Air Quality (CMAQ) model most often use an adaptation of the YL scheme to quantify soil NO emissions as a function of fertilizer application, soil moisture, precipitation, and CRF (Byun and Schere, 2006). However, YL has been found to underestimate emissions rates inferred from satellite and ground measurements by a factor ranging from 1.5 to 4.5 , and to misrepresent some key spatial and temporal features of emissions (Jaeglé et al., 2005; Wang et al., 2007; Boersma et al., 2008; Zhao and Wang, 2009; Lin, 2012; Hudman et al., 2012; Vinken et al., 2014). This overall underestimation can be attributed to several uncertainties in the modeling settings, such as inaccurate emissions coefficients, poor soil moisture data, deriving soil temperatures from ground air temperatures, neglecting nitrogen deposition, and outdated fertilizer application rates (Yienger and Levy, 1995; Jaeglé et al., 2005; Delon et al., 2007; Wang et al., 2007; Boersma et al., 2008; Delon et al., 2008; Hudman et al., 2010; Steinkamp and Lawrence, 2011; Hudman et al., 2012).

The Berkley Dalhousie Soil NO Parameterization (BDSNP) scheme, originally implemented by Hudman et al. (2012) in the GEOS-Chem global chemical transport model, outperforms YL by better representing biome type, the timing of emissions, and actual soil temperature and moisture (Hudman et al., 2010).

We implement BDSNP in CMAQ by using the Environmental Policy Integrated Climate (EPIC) biogeochemical model for dynamic representation of the soil $\mathrm{N}$ pool on a day-to-day basis. EPIC is a field-scale biogeochemical process model developed by the United States Department of Agriculture (USDA) to represent plant growth, soil hydrology, and soil heat budgets for multiple soil layers of variable thickness, multiple vegetative systems, and crop management practices (Cooter et al., 2012). EPIC can model up to $1 \mathrm{~km}^{2}$ (100 ha) spatially and on a daily timescale (CMAS, 2015; Cooter et al., 2010). EPIC simulations are compatible with spatial and temporal scale of CMAQ as well (Bash et al., 2013). EPIC accounts for different agricultural management scenarios, accurate simulation of soil conditions and plant growth to produce plan demand-driven fertilizer estimates for BDSNP (Cooter et al., 2012; Bash et al., 2013).

Baseline soil NO emission rate for each location (Hudman et al., 2012; Vinken et al., 2014), use a new soil biome map 
with finer-scale representation of land cover systems consistent with typical resolution of a regional model. We also built an offline version of BDSNP, which can use benchmarked inputs from the CMAQ and allows quick diagnostic based on soil NO estimates for sensitivity analysis (Supplement Sect. S2).

\section{Methodology}

\subsection{Implementation of advanced soil NO parameterization in CMAQ}

\subsubsection{Land surface model}

Our implementation of the BDSNP soil NO parameterization in CMAQ uses Pleim-Xiu Land Surface Model (Pleim and Xiu, 2003). Compared to the coarser land surface model (LSM) in GEOS-Chem (Bey et al., 2001), Pleim-Xiu provides finer-scale estimates of soil moisture and soil temperature based on solar radiation, temperature, leaf area index (LAI), vegetation coverage, and aerodynamic resistance. The rich amount of information available from the Pleim-Xiu LSM enables refined representation of soil moisture and soil temperature for implementation in soil NO parameterization.

\subsubsection{Canopy reduction factor}

The original implementation of BDSNP in GEOS-Chem did not provide specific spatial-temporal variation of CRF in each modeling grid, but used a monthly average CRF from Wang et al. (1998). Wang et al. (1998) included an updated CRF as part of their implementation of YL into GEOSChem. This CRF is based on wind speed, turbulence, canopy structure, deposition constants, and other physical variables. In the GEOS-Chem implementation of BDSNP, this CRF reduced the flux by $\sim 16 \%$, from $10.7 \mathrm{Tg} \mathrm{N} \mathrm{yr}^{-1}$ above soil to $9 \mathrm{Tg} \mathrm{N} \mathrm{yr}^{-1}$ above canopy (Hudman et al., 2012).

Our BDSNP implementation for CMAQ uses the same approach of integrating CRF as used in Wang et al. (1998) with the biome categorization based on Steinkamp and Lawrence (2011) and Köppen climate classes (Kottek et al., 2006) in the soil $\mathrm{NO}_{x}$ parameterization itself.

\subsubsection{Fertilizer}

YL in CMAQ assumed a linear correlation between fertilizer application and its induced emissions over the general growing season: May-August in the Northern Hemisphere and November-February in the Southern Hemisphere (Yienger and Levy, 1995), rather than peaking near the time of fertilization at the beginning of the local growing season. This likely caused inaccurate temporal representation of fertilizerdriven emissions in certain regions (Hudman et al., 2012). The GEOS-Chem implementation of BDSNP applied a longterm average fertilizer application with a decay term after fertilizer is applied. Constant fertilizer emissions neglect an important phenomenon: applying fertilizer during a dry period when neither plants nor bacteria may have the water available to use it may result in a large pulse when the soil is eventually re-wetted (Pilegaard, 2013). Such dry spring N fertilizer application is common practice in the Midwest and Southern Plains in the USA (Cooter et al., 2012). The current fertilizer data used for the BDSNP are scaled to global 2006 emissions by Hudman et al. (2012) using a spatial distribution for year 2000 from Potter et al. (2010). This global database reported by Potter et al. (2010) is already 8 years out of date in magnitude and 14 years out of date for relative distribution, and has relatively coarse resolution based on a out-of-date long-term average (national-level fertilizer data from 1994 to 2001). Using recent fertilizer application information is essential to soil NO estimates given the fact that $\mathrm{N}$ fertilizer is the major contributor to plant nutrient use in USA, and its share has been increasing from 11535000 short tons in 2001 to 12840000 short tons in 2013 (USDA ERS, 2013). Our implementation of BDSNP into CMAQ is designed to enable updates by subsequent developers to use new year- and location-specific fertilizer data. We use the Fertilizer Emission Scenario Tool for CMAQ (FEST-C v1.1; http://www.cmascenter.org) to incorporate EPIC simulations for 2011 into our CMAQ runs. Land use and management practices (type and timing of farm practices such as tillage) in EPIC are updated annually based on the USDA Agricultural Resource Management Survey (ARMS) (Cooter et al., 2012).

\subsubsection{N deposition}

YL in CMAQ neglects nitrogen deposition, which can result in a $0.5 \mathrm{Tg} \mathrm{yr}^{-1}$ underestimation in soil $\mathrm{NO}_{x}$ globally ( $\sim 5 \%)$ (Hudman et al., 2012). The current implementation of the EPIC model in FEST-C inputs oxidized and reduced forms of $\mathrm{N}$ deposition directly into soil nitrate and ammonium pools each day. In our implementation of BDSNP, these daily time series derive from previous CMAQ simulation. Inclusion of this deposition $\mathrm{N}$ source reduces the simulated plant-based demand for additional $\mathrm{N}$ fertilizer applications. This reduced fertilizer demand due to additional deposition source is based on the theoretical plant nutrient cycle and is implicit to how actual farming practices are applied in EPIC. The bi-directional exchange capability of CMAQ is also included, but currently it affects the ammonium pool only (Bash et al., 2013).

\subsubsection{Formulation of soil NO scheme}

Figure 1 provides the flow chart of the BDSNP scheme implementation, which has the option to run in-line with CMAQ, or as an offline emissions parameterization. Static input files in the Hudman et al. (2012) BDSNP implementation (labeled as "old" in Fig. 1), such as those giving soil 


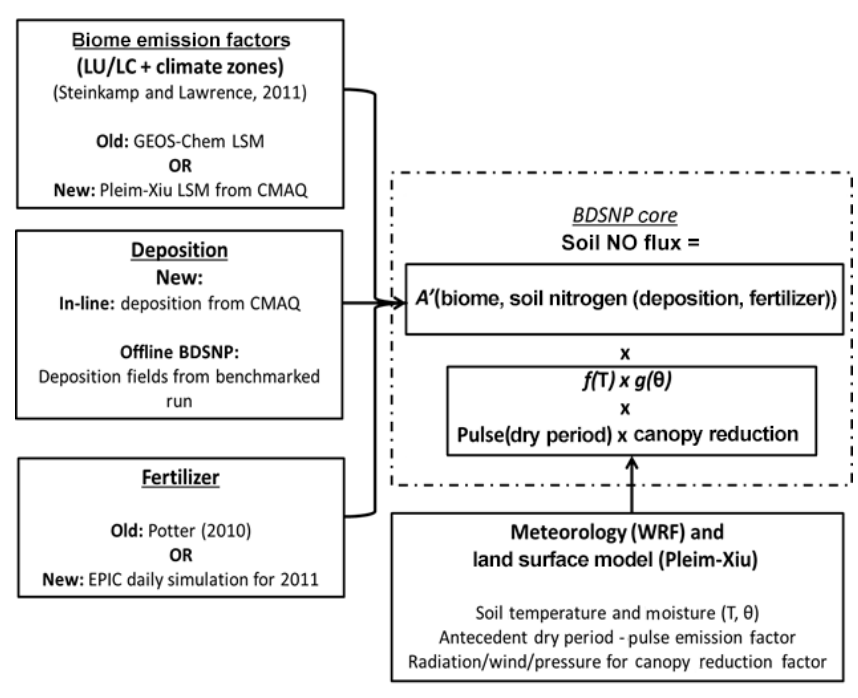

Figure 1. Soil NO emissions modeling framework as implemented offline or in CMAQ (in-line). "Old" refers to the Hudman et al. (2012) implementation in GEOS-Chem. "New" refers to our implementation in CMAQ.

biome type with climate zone and global fertilizer pool, are needed to determine the soil base emission value at each modeling grid. The Meteorology-Chemistry Interface Processor (MCIP) (Otte and Pleim, 2010) takes outputs from a meteorological model such as Weather Research and Forecasting (WRF) model (Skamarock et al., 2008) to provide a complete set of meteorological data needed for emissions and air quality simulations.

There are seven key input environment variables and two key output environment variables in our implementation of BDSNP. Table S1 lists their names and corresponding functionalities.

Our implementation of the BDSNP soil $\mathrm{NO}_{x}$ emission, $S_{\mathrm{NO}_{x}}$, in CMAQ multiplies a base emission factor $(A)$ by scaling factors dependent on soil temperature $(T)$ and soil moisture $(\theta)$, i.e., $f(T), g(\theta)$, and a pulsing term $(P)$ (Eq. 1). The base emission factor depends on biome type under wet or dry soil conditions. The pulsing term depends on the length of the dry period, rather than the accumulated rainfall amount considered by YL. The CRF-term estimates the fractional reduction in soil $\mathrm{NO}_{x}$ flux due to canopy resistance.

$$
\begin{aligned}
& S_{\mathrm{NO}_{x}} \text { Flux }\left(\frac{\mathrm{ngN}}{\mathrm{m}^{2} \mathrm{~s}}\right)=A_{\text {biome }}^{\prime}\left(\mathrm{N}_{\text {avail }}\right) \times f(T) \times g(\theta) \\
& \quad \times P\left(l_{\text {dry }}\right) \times \mathrm{CRF}(\mathrm{LAI}, \text { Meterology, Biome }) \\
& A_{\text {biome }}^{\prime}=A_{\text {biome }}+\mathrm{N}_{\text {avail }} \times \bar{E} \\
& \mathrm{~N}_{\text {avail }}(t)=\mathrm{N}_{\text {avail Fert }}(0) \times e^{-\frac{t}{\tau_{1}}}+F \times \tau_{1} \times\left(1-e^{-\frac{t}{\tau_{1}}}\right) \\
& \quad+\mathrm{N}_{\text {avail Dep }}(0) \times e^{-\frac{t}{\tau_{2}}}+D \times \tau_{2} \times\left(1-e^{-\frac{t}{\tau_{2}}}\right)
\end{aligned}
$$

Fertilizer and deposition both contribute to modifying the $A_{\text {biome }}^{\prime}$ emissions coefficients for each biome. Available ni- trogen $\left(\mathrm{N}_{\text {avail }}\right)$ at time $t$ from fertilizer and deposition is multiplied by emission rate, $\bar{E}$, based on the observed global estimates of fertilizer emissions $\left(\sim 1.8 \mathrm{Tg} \mathrm{N} \mathrm{yr}^{-1}\right)$ by Stehfest and Bouwman (2006) and added to biomespecific soil NO emission factors $\left(A_{\text {biome }}\right)$ from Steinkamp and Lawrence (2011) to give the net base emission factor ( $A_{\text {biome }}^{\prime}$ ) (Eqs. 2 and 3). The resulting $A^{\prime}$ is multiplied by the meteorological scaling or response factors: $f(T), g(\theta)$, and $P\left(l_{\text {dry }}\right)$ as in Eq. (1). The soil temperature response or scaling factor $f(T)$ is simplified to be exponential everywhere. NO flux now depends on soil moisture $(\theta)$ instead of rainfall, and it increases smoothly to a maximum value before decreasing as the ground becomes water saturated. In Eq. (3), $F$ is fertilization rate $\left(\mathrm{kg} \mathrm{ha}^{-1}\right), D$ is the wet and dry deposition rate $\left(\mathrm{kg} \mathrm{ha}^{-1}\right)$ considered as an additional fertilization rate, and $\tau$ is decay time, which is 4 months for fertilizer $\left(\tau_{1}\right)$ and 6 months for deposition ( $\tau_{2}$ ) (Hudman et al., 2012).

BDSNP uses a Poisson function to represent the dependence of emission rates on soil moisture $(\theta)$, where the parameters $a$ and $b$ vary for different climates such that the maximum of the function occurs at $\theta=0.2$ for arid soils and $\theta=0.3$ otherwise (Hudman et al., 2012). We adopt the same approach in CMAQ as follows:

$f(T) \times g(\theta)=e^{0.103 \times T} \times a \times \theta \times e^{-b \times \theta^{2}}$.

The pulsing term depends on the length of the dry period $\left(l_{\text {dry }}\right)$ and a change in soil moisture instead of on the amount of precipitation (Hudman et al., 2012).

The pulsing term for emissions when rain follows a dry period is

$P\left(l_{\text {dry }}, t\right)=\left[13.01 \times \ln \left(l_{\text {dry }}\right)-53.6\right] \times e^{-c \times t}$.

In this equation, $l_{\mathrm{dry}}$ is the length of the dry period that preceded the rain and $c=0.068 \mathrm{~h}^{-1}$ defines the exponential decay of the pulse.

Beyond this basic implementation of the above stated BDSNP framework into CMAQ, there were major modifications (highlighted as "new" in Fig. 1) in the form of (a) updating biome map consistent with CMAQ, (b) incorporating yearand location-specific fertilizer data using EPIC outputs, and (c) development of an offline BDSNP module. Our work focuses on those developments discussed in detail in the sections to follow.

\subsection{Soil biome map over CONUS}

The original implementation of BDSNP used the global soil biome data from the GEOS-Chem, with emission factors for each biome under dry/wet conditions taken from Steinkamp and Lawrence (2011) (Appendix Table A1). Our implementation in CMAQ uses a finer resolution $(12 \mathrm{~km})$ soil biome map over CONUS. The map is generated from the 30 arcsec (approximately $1 \mathrm{~km}$ ) NLCD40 (National Land Cover Dataset) for 2006, with 40 land cover/land use classifications. A mapping algorithm table (see Appendix Table A2) 


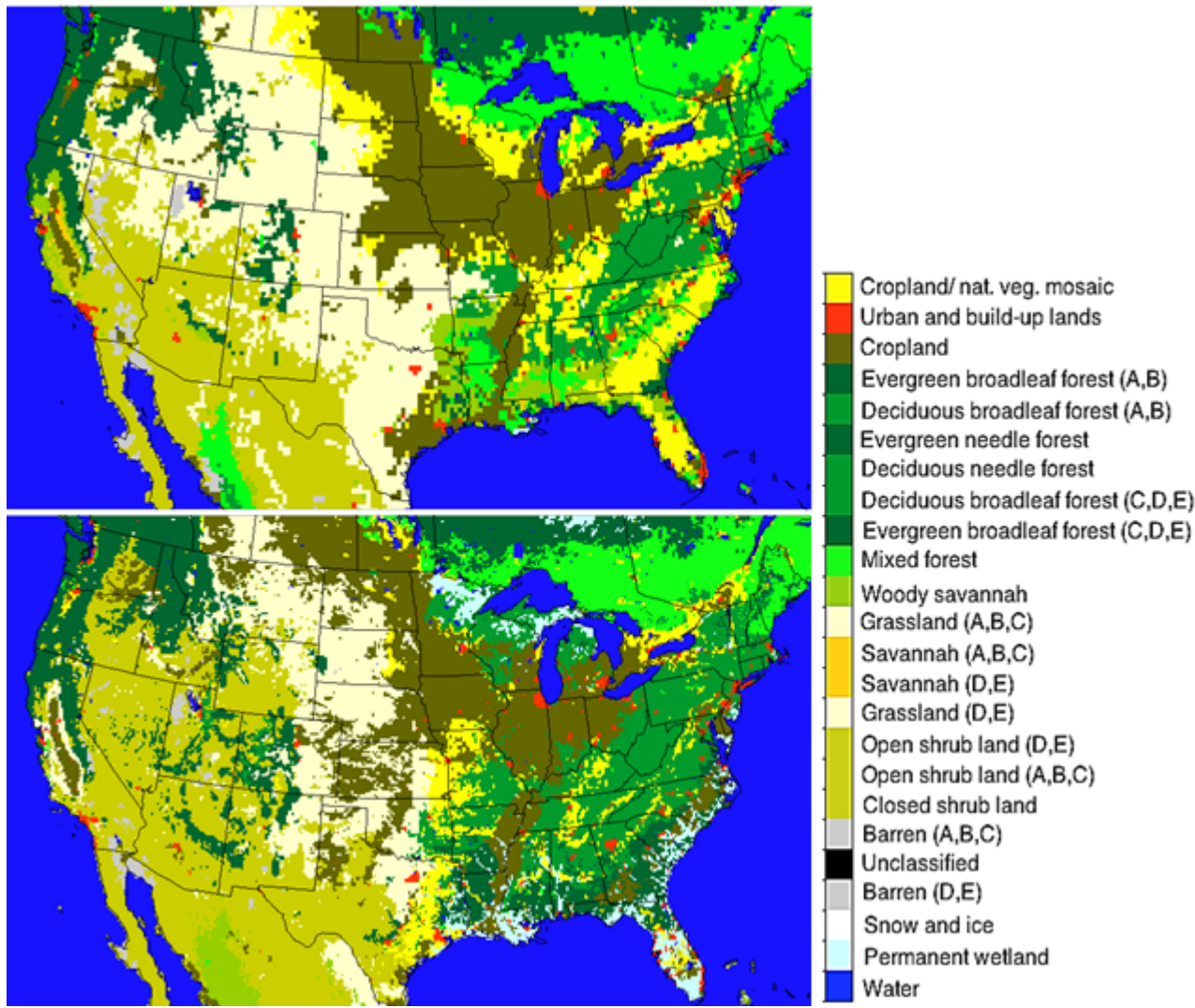

Figure 2. Biomes from GEOS-Chem $\left(0.25^{\circ} \times 0.25^{\circ}\right.$; top $)$ and CMAQ MODIS NLCD40 $(12 \mathrm{~km} \times 12 \mathrm{~km}$; bottom $)$ regrouped to match the classifications for which emission factors are available from Steinkamp and Lawrence (2011). See Tables A1 and A2 (right) for the mappings between classifications. The color-bar legends for classifications are as per NLCD definitions (http://www.mrlc.gov/nlcd11_leg.php).

was created to connect the land use category to soil biome type (Table A1) based on best available knowledge. For the categories with identical names, such as "evergreen needleleaf forest", "deciduous needleleaf forest", "mixed forest", "savannas", and "grassland", the mapping is direct. Categories in NLCD40, which are subsets of the corresponding biome category, are consolidated into one category by addition. For example, "permanent snow and ice" and "perennial ice-snow" in NLCD40 are combined to form "snow and ice"; "developed open space", "developed low intensity", "developed medium intensity", and "developed high intensity" are added to form "urban and built-up lands". For the categories appearing only in NLCD40, the mapping algorithm is determined by referring to the CMAQ mapping scheme, available in cross section and quantum yield (CSQY) data files in the CMAQ coding. One such case is to map "lichens" and "moss" in NLCD40 to the category "grassland" in soil biome. Furthermore, a model resolution compatible Köppen climate zone classification (Kottek et al., 2006) was added to allocate different emission factor for the same biome type, e.g., to account for different altitudes of "grassland" at different locations. There are five climate zone classifications, namely A: equatorial, B: arid, C: warm temperature, D: snow, and E: polar. A $12 \mathrm{~km}$ CONUS model resolution climate zone classification map (see Fig. 2) was created using the Spatial Allocator based on the county level climate zone definition as the surrogate based on a dominant land use (http://koeppen-geiger. vu-wien.ac.at/data/KoeppenGeiger.UScounty.txt)

Figure 2 compares the 24 -soil biome map with $0.25^{\circ}$ resolution from the GEOS-Chem settings to the new $12 \mathrm{~km}$ resolution soil biome map we created here for CMAQ. Table $\mathrm{A} 2$ gives the biome type names with corresponding climate zones.

The classification of simulation domain into arid and nonarid region with consistent resolution is also included in our implementation. Figure B1 shows the distribution of arid (red) and non-arid (blue) regions. For the modeling grid classified as "arid" region, the maximum moisture scaling factor corresponds to the water-filled pore space $(\theta)$ value equal to 0.2 ; while for the "non-arid" modeling grid, the maximum moisture scaling factor corresponds with $\theta=0.3$ (Hudman et al., 2012). 


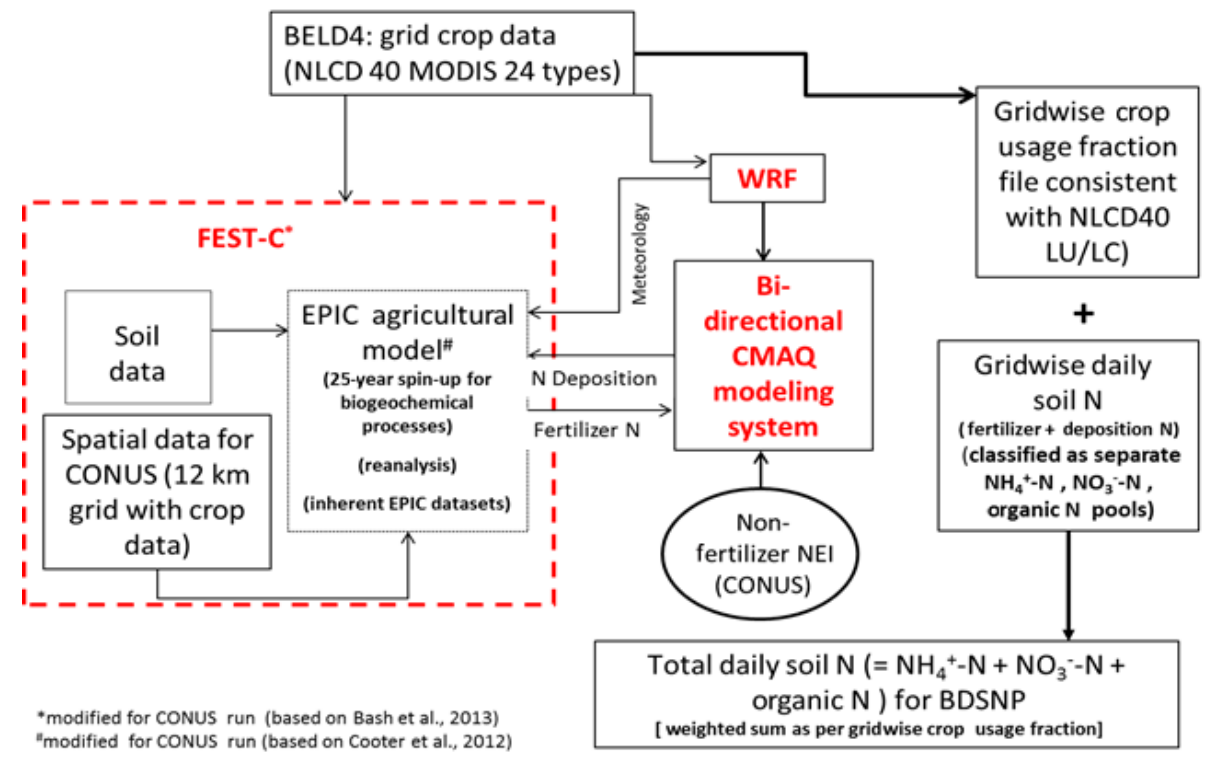

Figure 3. Modeling framework for obtaining total soil N from EPIC using FEST-C.

\subsection{Representation of fertilizer $\mathbf{N}$}

We implemented two approaches for representing fertilizer $\mathrm{N}$. The first approach re-grids fertilizer data from the global GEOS-Chem BDSNP implementation (Hudman et al., 2012) to our $12 \mathrm{~km}$ resolution CONUS domain. That scheme uses the global fertilizer database from Potter et al. (2010) and assumed $37 \%$ of fertilizer and manure $\mathrm{N}$ is available $\left(1.8 \mathrm{Tg} \mathrm{N} \mathrm{yr}^{-1}\right)$ for potential emission. Figure B2 provides the day-by-day variation of total $\mathrm{N}$ remaining due to fertilizer application over CONUS during a year, and shows the typical cycle between growing season and non-growing season. The Potter et al. (2010) data, however, are a decade old and at coarse resolution for county level in USA.

Our second approach (Fig. 3) uses the EPIC model as implemented in the FEST-C tool (Cooter et al., 2012) to provide a dynamic representation of fertilizer applications for a specific growing season. FEST-C (v1.1) generates modelready fertilizer input files for CMAQ. Use of FEST-C/EPIC instead of soil emissions from YL scheme has been shown to improve CMAQ performance for nitrate and ammonia in CONUS (Bash et al., 2013). The BELD4 tool in the FEST-C system was used to provide the crop usage fraction over our domain. We summed FEST-C data for ammonia, nitrate and organic (T1_ANH3, T1_ANO3, and T1_AON, respectively) in $\mathrm{kg} \mathrm{Nha}^{-1}$, to give a total soil $\mathrm{N}$ pool for each of 42 simulated crops (CMAS, 2015). This daily cropwise total soil $\mathrm{N}$ pool was then weighted by the fraction of each crop type at each modeling grid to get a final weighted sum total soil $\mathrm{N}$ pool usable in BDSNP. CMAQ v.5.0.2 can be run with in-line biogenic emissions, calculated in tandem with the rest of the model. Since the EPIC N pools already include $\mathrm{N}$ deposition, we designed our soil $\mathrm{NO}$ emissions module to be flexible in recognizing whether it is using fertilizer data (e.g., Potter et al., 2010) that do not include deposition or EPIC that does.

Figure 4 compares the FEST-C-derived $\mathrm{N}$ fertilizer map and the default coarser resolution long-term average fertilizer map from Potter et al. (2010). While the spatial patterns are similar, EPIC provides finer resolution and more up-to-date information.

\subsection{Model configurations and data use for model evaluations}

The CMAQ domain settings for CONUS as provided by the EPA were used to simulate the whole month of July in 2011. July corresponds to the month of peak flux for soil nitrogen emissions in the USA (Williams et al., 1992; Cooter et al., 2012; Bash et al., 2013) and is an active period for ozone photochemistry (Cooper et al., 2014; Strode et al., 2015).

A 10-day (21-30 June 2011) spin-up time was used to minimize the influence from initial conditions. The domain consisted of 396 columns, 246 rows, 26 vertical layers, and $12 \mathrm{~km}$ rectangular cells using a Lambert Conformal Projection over North America. This configuration was consistent throughout the WRF-BDSNP-CMAQ modeling framework (see Fig. 1). Meteorology data were produced through the WRF Model nudged to National Centers for Environmental Prediction (NCEP) and National Center for Atmospheric Research Reanalysis (NARR) data, which is comprised of historical observations and processed to control quality and consistency across years by National Oceanic and Atmospheric Administration (NOAA). Emissions were generated using the Sparse Matrix Operator Kernel Emissions (SMOKE) model (CMAS, 2014) and 2011NEIv1. CMAQ was applied 


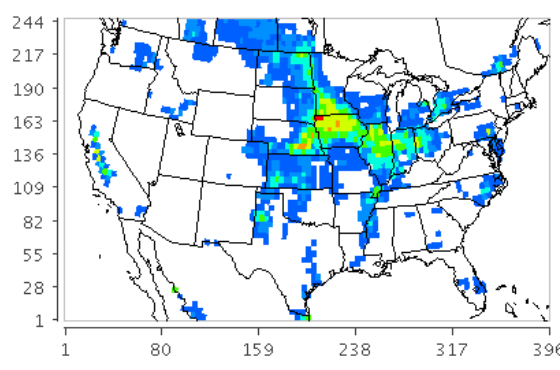

$\operatorname{Min}(1,1)=0.0, \operatorname{Max}(209,164)=76.8$

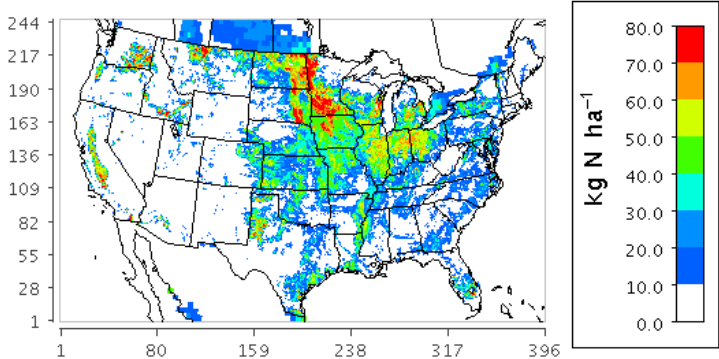

$\operatorname{Min}(1,1)=0.0, \operatorname{Max}(207,211)=115.5$

Figure 4. Potter et al. (2010) (left) and EPIC (right) annual fertilizer applications $\left(\mathrm{kg} \mathrm{N} \mathrm{ha}^{-1}\right)$. Since the EPIC modeled is only for the USA, Potter et al. (2010) is used in both cases to represent Canada and Mexico.

with bi-directional exchange of ammonia between soils and atmosphere.

We applied CMAQ with three sets of soil NO emissions: (a) standard YL soil NO scheme, (b) BDSNP scheme with Potter et al. (2010) fertilizer data set and biome mappings from GEOS-Chem, and (c) BDSNP scheme with EPIC 2011 data and new biome mappings (see Appendix Table A3). Within these three cases, we simulated the impact of anthropogenic $\mathrm{NO}_{x}$ reductions applied to all contributing source sectors listed in the 2011 National Emission Inventory (NEI). For this purpose, we considered the baseline $\mathrm{NO}_{x}$ reduction scenario from 2011 to 2025 that EPA's Regulatory Impact Analysis (RIA) determined for business as usual (BAU) in the CONUS domain (Fig. 2A-1, Table 2A-1 in https://www3. epa.gov/ttn/ecas/docs/20151001ria.pdf). Table 1 gives a full list of modeling configurations settings used for achieving the above-mentioned simulations.

Model simulations were evaluated against the following in situ and satellite-based data: 16 USEPA Clean Air Status and Trends Network (CASTNET) sites for MDA8 $\mathrm{O}_{3}$ (www.epa.gov/castnet), 9 Interagency Monitoring of Protected Visual Environments (IMPROVE) sites for daily average $\mathrm{PM}_{2.5}$ (Malm et al., 1994), and NASA's Ozone Monitoring Instrument (OMI) retrieval product for tropospheric $\mathrm{NO}_{2}$ column (Bucsela et al., 2013; Lamsal et al., 2014). Figure 5 shows the spatial distribution of the ground sites used for validation of modeled estimates. The selected ground sites for model validation are mostly based in agricultural regions with intense fertilizer application rate and high NO fluxes, specifically the Midwest, Southern Plains, and San Joaquin Valley.

We also simulated three sensitivity cases for the same time period and domain with the offline soil NO module: (a) NLCD40-based (new) biome vs. GEOS-Chem-based (old) biome (using EF1 in Table A1), (b) EPIC 2011 vs. Potter et al. (2010) data, and (c) global mean biome emission factor (EF1 in Table A1) vs. North American mean emission factor (EF3 in Table A1) (Supplement Sect. S3).

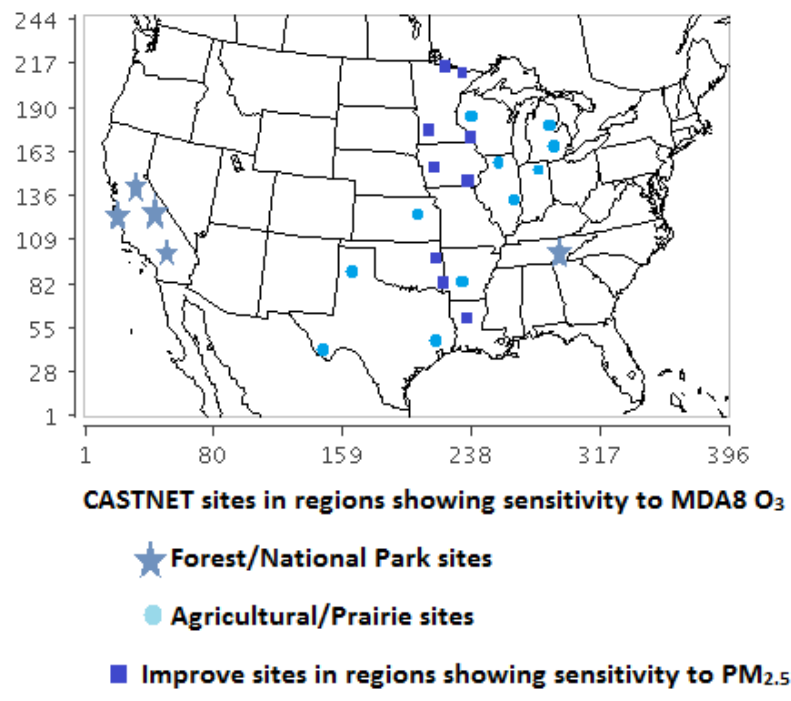

Figure 5. CASTNET (forest/national park and agricultural sites) and IMPROVE sites in continental USA for comparison of modeled and observed ozone and $\mathrm{PM}_{2.5}$.

\section{Results and discussion}

\subsection{Spatial distribution of nitrogen fertilizer application and soil NO emissions over CONUS}

We demarcated the CONUS domain into six sub-domains (Fig. 6) to analyze model outputs. The updated BDSNP model and EPIC fertilizer result in higher soil NO emission rates than YL and Potter et al. (2010). Emissions increase by a factor ranging from 1.8 to 2.8 in shifting from YL to BDSNP, even while retaining the Potter et al. (2010) fertilizer data and original biome map, indicating that the shift from the YL to the BDSNP scheme is the largest driver of the increase in emissions estimates. EPIC and the new biome data set further increase emissions over most of CONUS, except for the southwest region. In the Midwest and western USA, the new biome map identified more cropland and shifted 
Table 1. Modeling configuration used for the WRF-BDSNP-CMAQ CONUS domain runs.

\begin{tabular}{|c|c|c|c|}
\hline \multicolumn{4}{|l|}{ WRF/MCIP } \\
\hline Version: & ARW V3.6.1 & Shortwave radiation: & RRTMG scheme \\
\hline Horizontal resolution: & CONUS $(12 \mathrm{~km} \times 12 \mathrm{~km})$ & Surface layer physic: & Pleim-Xiu surface model \\
\hline Vertical resolution: & 26 layer & PBL scheme: & ACM2 \\
\hline Boundary condition: & NARR $32 \mathrm{~km}$ & Microphysics: & Morrison double-moment scheme \\
\hline Initial condition: & NCEP-ADP & Cumulus parameterization: & Kain-Fritsch scheme \\
\hline Longwave radiation: & RRTMG scheme & Assimilation: & $\begin{array}{l}\text { Analysis nudging above PBL for } \\
\text { temperature, moisture, and wind speed }\end{array}$ \\
\hline \multicolumn{4}{|l|}{ BDSNP } \\
\hline Horizontal resolution: & Same as WRF/MCIP & Emission factor: & Steinkamp and Lawrence (2011) \\
\hline \multirow[t]{4}{*}{ Soil biome type: } & 24 types based on & Fertilizer database: & EPIC 2011 based from \\
\hline & NLCD40 (new) & & FEST-C (new) \\
\hline & 24 types based on & & Potter et al. (2010) (old) \\
\hline & GEOS-Chem LSM (old) & & \\
\hline \multicolumn{4}{|l|}{ CMAQ } \\
\hline Version: & V5.02 & Anthropogenic emission: & NEI2011 \\
\hline Horizontal resolution: & Same as WRF/MCIP & Biogenic emission: & BEIS V3.1 in-line \\
\hline \multirow[t]{2}{*}{ Initial condition: } & Pleim-Xiu (new) & Boundary condition: & Pleim-Xiu (new) \\
\hline & GEOS-Chem (old) & & GEOS-Chem (old) \\
\hline Aerosol module: & AE5 & Gas-phase mechanism: & CB-05 \\
\hline \multicolumn{4}{|c|}{ Simulation case arrangement (in-line with CMAQ) } \\
\hline 1. YL: & \multicolumn{3}{|c|}{ WRF/MCIP-CMAQ with standard YL soil NO scheme } \\
\hline $\begin{array}{l}\text { 2. BDSNP (Potter et al., 2010, } \\
\text { with old Biome or "old"): }\end{array}$ & \multicolumn{3}{|c|}{ WRF/MCIP-BDSNP-CMAQ with Potter et al. (2010) and old biome } \\
\hline $\begin{array}{l}\text { 3. BDSNP (EPIC with } \\
\text { new Biome or "new"): }\end{array}$ & \multicolumn{3}{|c|}{ WRF/MCIP-BDSNP-CMAQ with EPIC and new biome } \\
\hline \multicolumn{4}{|l|}{ Simulation time period } \\
\hline & \multicolumn{3}{|c|}{$\begin{array}{l}\text { 1-31 July } 2011 \text { for CMAQ simulation with in-line soil NO BDSNP module } \\
\text { Daily simulations in Year } 2011 \text { for offline BDSNP soil NO BDSNP module } \\
\text { (1-31 July } 2011 \text { for sensitivity analysis) }\end{array}$} \\
\hline \multicolumn{4}{|l|}{ Model performance evaluation } \\
\hline \multicolumn{4}{|c|}{$\begin{array}{l}\text { USEPA Clean Air Status and Trends Network (CASTNET) data for MDA8 ozone } \\
\text { Interagency Monitoring of Protected Visual Environments (IMPROVE) Network (Malm et al., 1994) for PM} 2.5 \\
\mathrm{OMI} \mathrm{NO}_{2} \text { satellite retrieval product as derived in Lamsal et al. (2014) for } \mathrm{NO}_{2} \text { column }\end{array}$} \\
\hline
\end{tabular}

some grasslands to other land cover types such as forests, savannah, and croplands, which exhibit higher soil NO emissions (Fig. 2; Table A1). The Midwest region is characterized with the highest emission rate due to its abundant agricultural lands with high fertilizer application rates (Fig. 4).

\subsection{Evaluation of CMAQ $\mathrm{NO}_{2}$ with satellite $\mathrm{OMI} \mathrm{NO}_{2}$ observations}

The standard (version 2.1) OMI tropospheric $\mathrm{NO}_{2}$ column observations from NASA's Aura satellite as discussed in Bucsela et al. (2013) and Lamsal et al. (2014) were used for comparison with our modeled $\mathrm{NO}_{2}$ vertical columns. To enable comparison, the quality-assured, clear-sky (cloud radi- ance fraction <0.5) $\mathrm{OMI} \mathrm{NO}_{2}$ data were gridded and projected to our domain by using ArcGIS 10.3. CMAQ modeled $\mathrm{NO}_{2}$ column densities in molecules per $\mathrm{cm}^{2}$ were derived using vertical integration and extracted for 13:00-14:00 local time, corresponding to the time of OMI measurements.

We compared CMAQ simulated tropospheric $\mathrm{NO}_{2}$ columns with OMI product for regions showing the highest sensitivity in soil NO switching from YL to BDSNP: the Midwest, San Joaquin Valley in California, and central Texas (see Appendix Fig. B3). Switching from YL to our updated BDSNP (new) module improved agreement with $\mathrm{OMI} \mathrm{NO}_{2}$ columns in central Texas but over-predicts column $\mathrm{NO}_{2}$ in the San Joaquin Valley and the Midwest (Fig. 7). Even the 

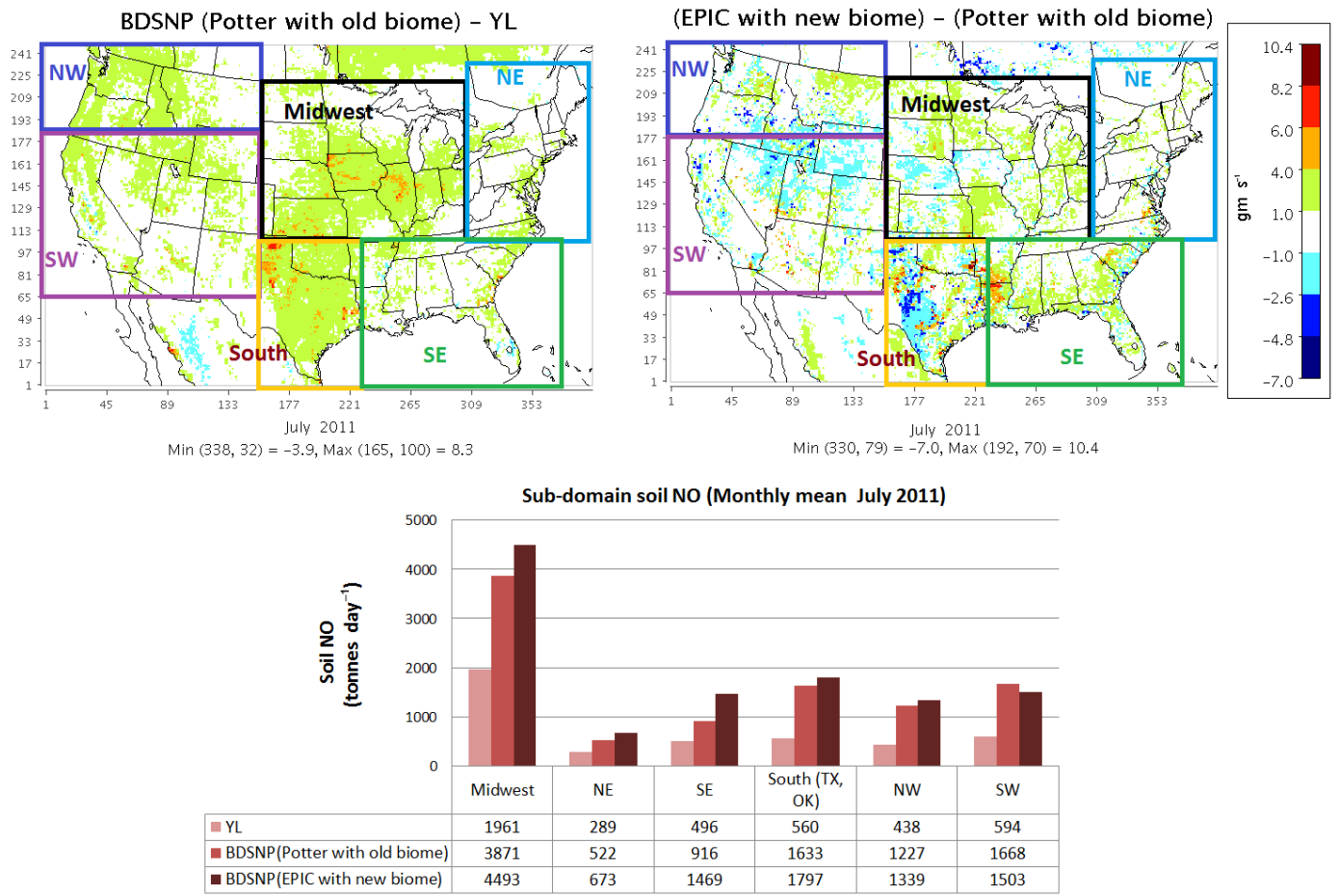

Figure 6. Soil NO (t day ${ }^{-1}$ ) sensitivity to change from YL to BDSNP ( et al. (2010) and old biome or "old") (left) and to the fertilizer and biome scheme within BDSNP (right) over sub-domains (boxes).

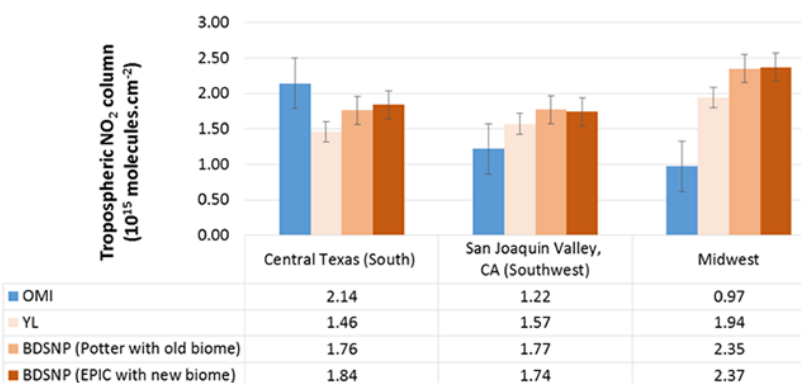

Figure 7. Spatial average for Tropospheric $\mathrm{NO}_{2}\left(\right.$ molecules $\left.\mathrm{cm}^{-2}\right)$ over regions with high soil NO sensitivity with switch from YL to BDSNP (as in Fig. 6) with comparison to $\mathrm{OMI} \mathrm{NO} 2 \cdot \mathrm{NO}_{2}$ column are temporal average for July 2011 at OMI overpass time.

YL estimate was higher than OMI by a factor of 2 in the Midwest (Fig. 7). Vinken et al. (2014) found the Midwestern USA to be one of the few regions globally where a BDSNPbased inventory over-predicted soil NO emissions inferred from OMI.

\subsection{Evaluation with $\mathbf{P M}_{2.5}$ and ozone observations}

Model results are compared with observational data from IMPROVE monitors for $\mathrm{PM}_{2.5}$ and CASTNET monitors for ozone. We first compute differences between ozone and $\mathrm{PM}_{2.5}$ estimates from the three simulation cases to identify sites influenced by the choice of soil NO scheme during our July 2011 episode (Figs. 8 and 9). Overall, analysis of variance and a $t$ test showed no statistically significant differences among the soil $\mathrm{NO}$ cases for $\mathrm{PM}_{2.5}$, but found the $\mathrm{YL}$ case to be significantly different $(p \ll 0.05)$ from the BDSNP cases for ozone. Closer examination highlights nine IMPROVE sites for $\mathrm{PM}_{2.5}$ and 16 CASTNET sites for ozone (Figs. 5, 8 and 9) where CMAQ results are sensitive to soil NO changes (Fig. 6).

Statistical comparisons of modeled and observed daily average $\mathrm{PM}_{2.5}$ at the nine IMPROVE sites are provided in Table 2. Mean absolute gross error (MAGE) and root mean square error (RMSE) improved from 2.8 to 2.7 and 3.4 to $3.3 \mu \mathrm{g} \mathrm{m}^{-3}$, respectively, when moving from YL to BDSNP with the new inputs. Both Pearson's and Spearman's ranked correlation coefficient $(R)$ show no significant change when the soil NO module in CMAQ is switched from YL to BDSNP (et al. (2010) with old biome) and BDSNP (EPIC with new biome) (Table 2). Use of the ranked correlation coefficient minimizes the impact of spurious correlations due to outliers but does not affect the analysis. Switching from YL to our updated BDSNP (new) module shows that the predicted vs. observed fit becomes slightly closer to $1: 1$ (Fig. 10). Numerical mean bias (NMB) and numerical mean error (NME) improve from -28.5 to -26.4 and 34.6 to $33.6 \%$, respectively. 


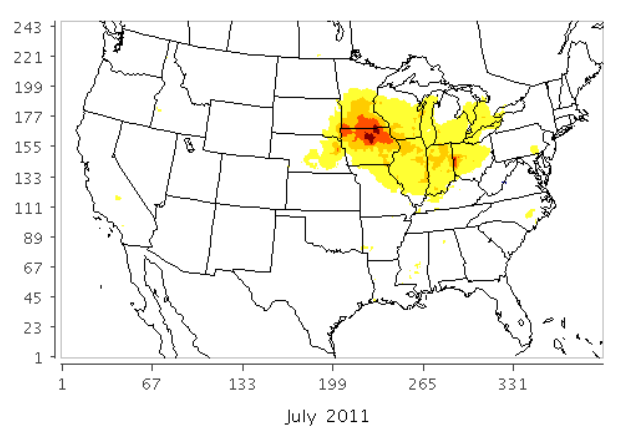

$\operatorname{Min}(323,129)=-0.1, \operatorname{Max}(231,168)=0.7$

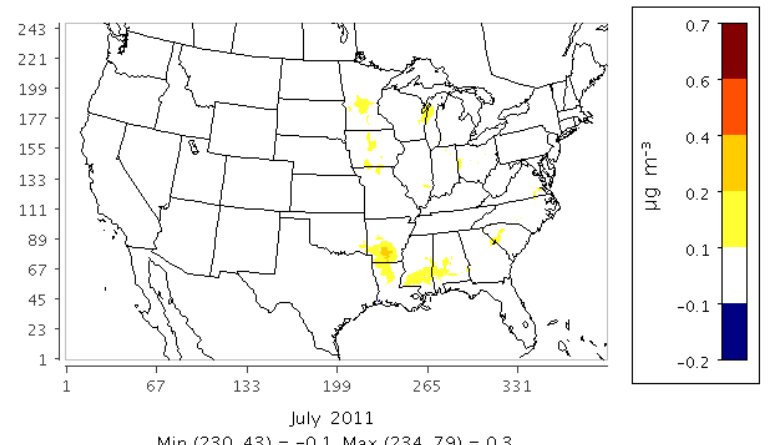

$\operatorname{Min}(230,43)=-0.1, \operatorname{Max}(234,79)=0.3$

Figure 8. Changes in modeled daily average $\mathrm{PM}_{2.5}$ when switching from (a) YL to BDSNP ( et al. (2010) fertilizer data with original biome map) (left) and (b) BDSNP ( et al. (2010) with original biomes) to BDSNP (EPIC with new biomes) (right).
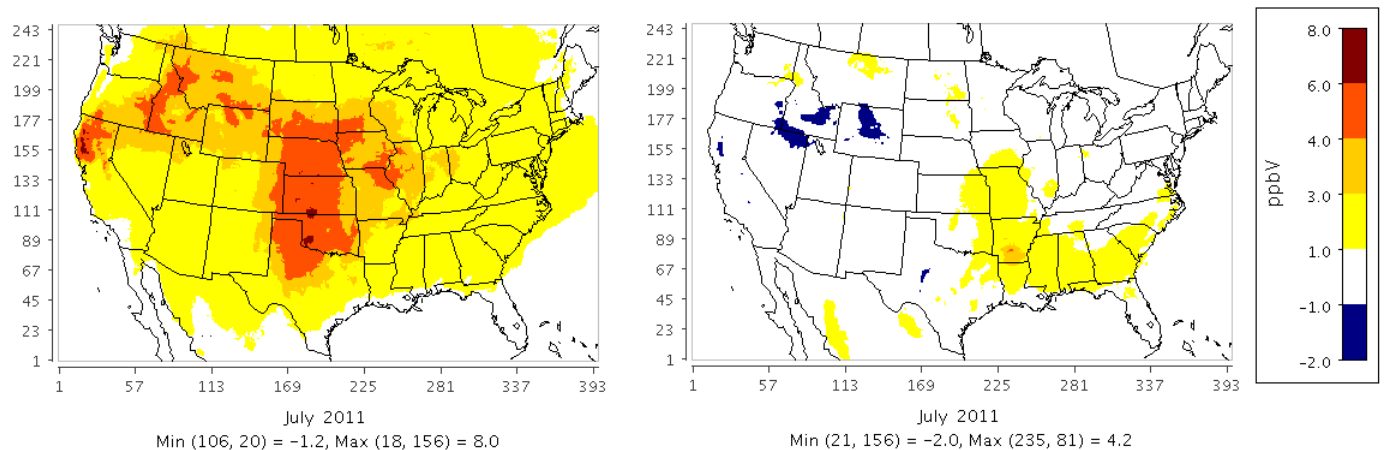

Figure 9. Changes in modeled maximum daily $8 \mathrm{~h}$ ozone (MDA8) when switching from (a) YL to BDSNP ( et al. (2010) fertilizer data with original biome map) (left) and (b) BDSNP ( et al. (2010) with original biomes) to BDSNP (EPIC with new biomes) (right).

Table 2. Aggregated performance statistics of CMAQ modeled daily average $\mathrm{PM}_{2.5}$ for stations showing sensitivities with change in soil NO between the YL scheme and our two in-line BDSNP implementations ("old" and "new") for CONUS in July 2011 as compared to observations at these sites.

\begin{tabular}{|c|c|c|c|c|c|}
\hline \multicolumn{6}{|c|}{ Metrics } \\
\hline \multirow{10}{*}{$\begin{array}{l}\text { Daily average } \mathrm{PM}_{2.5} \\
\text { July (1-31 July), } \\
2011\end{array}$} & \multicolumn{2}{|l|}{ Sample size } & \multicolumn{3}{|c|}{81} \\
\hline & \multicolumn{2}{|l|}{ Mean observed $\left(\mu \mathrm{g} \mathrm{m}^{-3}\right)$} & \multicolumn{3}{|c|}{8.26} \\
\hline & \multicolumn{2}{|l|}{3 CMAQ in-line cases } & YL & $\begin{array}{l}\text { BDSNP (Potter et al., } \\
\text { 2010, with old biome) }\end{array}$ & $\begin{array}{r}\text { BDSNP (EPIC } \\
\text { with new biome) }\end{array}$ \\
\hline & \multicolumn{2}{|l|}{ Mean predicted $\left(\mu \mathrm{g} \mathrm{m}^{-3}\right)$} & 5.91 & 6.04 & 6.08 \\
\hline & \multicolumn{2}{|c|}{ MAGE (mean absolute gross error) } & 2.86 & 2.80 & 2.77 \\
\hline & \multicolumn{2}{|l|}{ RMSE } & 3.45 & 3.40 & 3.38 \\
\hline & \multirow[t]{2}{*}{$R$ (correlation coefficient) } & Pearson's & 0.72 & 0.71 & 0.71 \\
\hline & & Spearman's ranked & 0.65 & 0.63 & 0.63 \\
\hline & \multicolumn{2}{|l|}{ NMB $(\%)$} & -28.52 & -26.90 & -26.44 \\
\hline & \multicolumn{2}{|l|}{ NME (\%) } & 34.64 & 33.88 & 33.57 \\
\hline
\end{tabular}




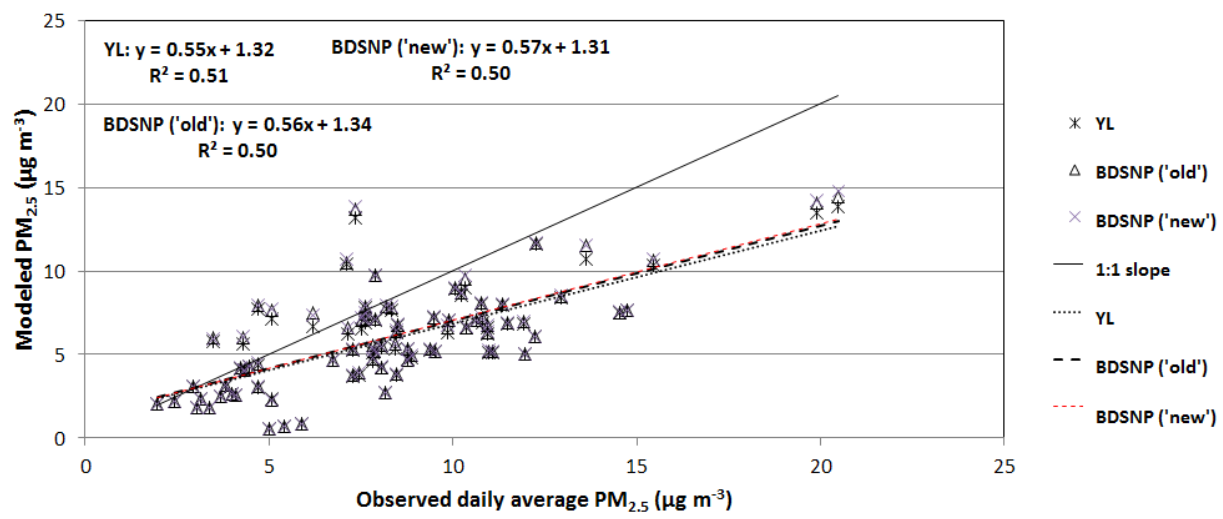

Figure 10. Comparison of the three in-line BDSNP-CMAQ cases with IMPROVE PM 2.5 data (Malm et al., 1994) in continental USA for the daily average $\mathrm{PM}_{2.5}$ for July 2011.

Table 3. Performance statistics of CMAQ modeled MDA8 Ozone for 16 CASTNET remote sites grouped into two categories: (a) 11 sites with moist or wet soil condition (monthly mean soil moisture $\left(\mathrm{m}^{3} \mathrm{~m}^{-3}\right), \theta_{\text {mean }}>0.175$ ), and (b) five sites with dry soil condition $\left(\theta_{\text {mean }}<0.175\right.$ ), using soil NO from YL and our two in-line BDSNP schemes.

\begin{tabular}{|c|c|c|c|c|c|}
\hline \multirow{5}{*}{$\begin{array}{l}\text { July } 2011 \\
11 \text { CASTNET sites } \\
\text { (mostly agricultural/prairie } \\
\text { sites, mostly wet } \\
\text { soil conditions) }\end{array}$} & \multicolumn{2}{|c|}{ Metrics } & \\
\hline & \multicolumn{2}{|l|}{ Sample size } & \multicolumn{3}{|c|}{311} \\
\hline & \multicolumn{2}{|l|}{ Mean observed (ppbv) } & \multicolumn{3}{|c|}{51.76} \\
\hline & \multirow{2}{*}{\multicolumn{2}{|c|}{3 CMAQ in-line cases }} & YL & BDSNP (Potter et al., & BDSNP (EPIC \\
\hline & & & & 2010 , with old biome) & with new biome) \\
\hline & \multicolumn{2}{|l|}{ Mean modeled (ppbv) } & 55.25 & 57.93 & 58.60 \\
\hline & \multicolumn{2}{|c|}{$M_{\mathrm{AGE}}$ (mean absolute gross error) } & 7.78 & 9.16 & 9.65 \\
\hline & \multicolumn{2}{|l|}{ RMSE } & 9.41 & 10.96 & 11.47 \\
\hline & \multirow[t]{2}{*}{$R$ (correlation coefficient) } & Pearson's & 0.50 & 0.51 & 0.50 \\
\hline & & Spearman's ranked & 0.46 & 0.49 & 0.48 \\
\hline & \multicolumn{2}{|l|}{ NMB $(\%)$} & 7.57 & 12.80 & 14.08 \\
\hline & \multicolumn{2}{|l|}{ NME $(\%)$} & 15.65 & 18.38 & 19.33 \\
\hline \multirow{9}{*}{$\begin{array}{l}5 \text { CASTNET sites (mostly } \\
\text { forest/National Park } \\
\text { sites near the San Joaquin Valley, } \\
\text { CA, dry soil conditions) }\end{array}$} & \multicolumn{2}{|l|}{ Sample size } & \multicolumn{3}{|c|}{147} \\
\hline & \multicolumn{2}{|l|}{ Mean observed (ppbv) } & \multicolumn{3}{|c|}{64.38} \\
\hline & \multicolumn{2}{|c|}{ Mean modeled (ppbv) } & 55.17 & 57.01 & 56.87 \\
\hline & \multicolumn{2}{|c|}{$M_{\mathrm{AGE}}$ (mean absolute gross error) } & 11.41 & 10.13 & 10.44 \\
\hline & \multicolumn{2}{|c|}{ RMSE } & 13.13 & 11.80 & 12.12 \\
\hline & \multirow[t]{2}{*}{$R$ (correlation coefficient) } & Pearson's & 0.71 & 0.72 & 0.72 \\
\hline & & Spearman's ranked & 0.68 & 0.69 & 0.69 \\
\hline & \multicolumn{2}{|l|}{$\operatorname{NMB}(\%)$} & -13.14 & -10.23 & -10.35 \\
\hline & \multicolumn{2}{|l|}{ NME (\%) } & 16.95 & 15.04 & 15.45 \\
\hline
\end{tabular}

In contrast to the $\mathrm{PM}_{2.5}$ results, the updated soil $\mathrm{NO}$ scheme yields mixed impacts on model performance for maximum daily average $8 \mathrm{~h}$ (MDA8) ozone at the targeted 16 CASTNET sites (Table 3 and Fig. 11). For the 11 agricultural/prairie sites, replacement of YL with BDSNP with new inputs increases NMB from 7.6 to $14.1 \%$ and NME from 15.7 to $19.3 \%$ (Table 3 ). The excess ozone may occur because FEST-C does not account for the loss of fertilizer $\mathrm{N}$ to the water stream (tile drainage) in wet conditions (Dinnes et al., 2002). Hudman et al. (2012) suggested $\theta=0.175\left(\mathrm{~m}^{3} \mathrm{~m}^{-3}\right)$ as the threshold below which dry condition occur. During July 2011, in Midwest monthly mean soil moisture $\left(\theta_{\text {mean }}, \mathrm{m}^{3} \mathrm{~m}^{-3}\right)$ is mostly $>0.175$, indicating the possibility of wet conditions (Fig. S5). Overestimation of $\mathrm{O}_{3}$ is due to higher $\mathrm{NO}$ emissions, as these regions comprise of mostly $\mathrm{NO}_{x}$ limited rural locations.

At the California CASTNET sites, BDSNP enhances model performance in simulating observed MDA8 ozone (Table 3). This can be seen in the NMB, NME, MAGE, and RMSE comparisons between YL and BDSNP, though updating BDSNP to the newer inputs does not enhance performance (Table 3). 

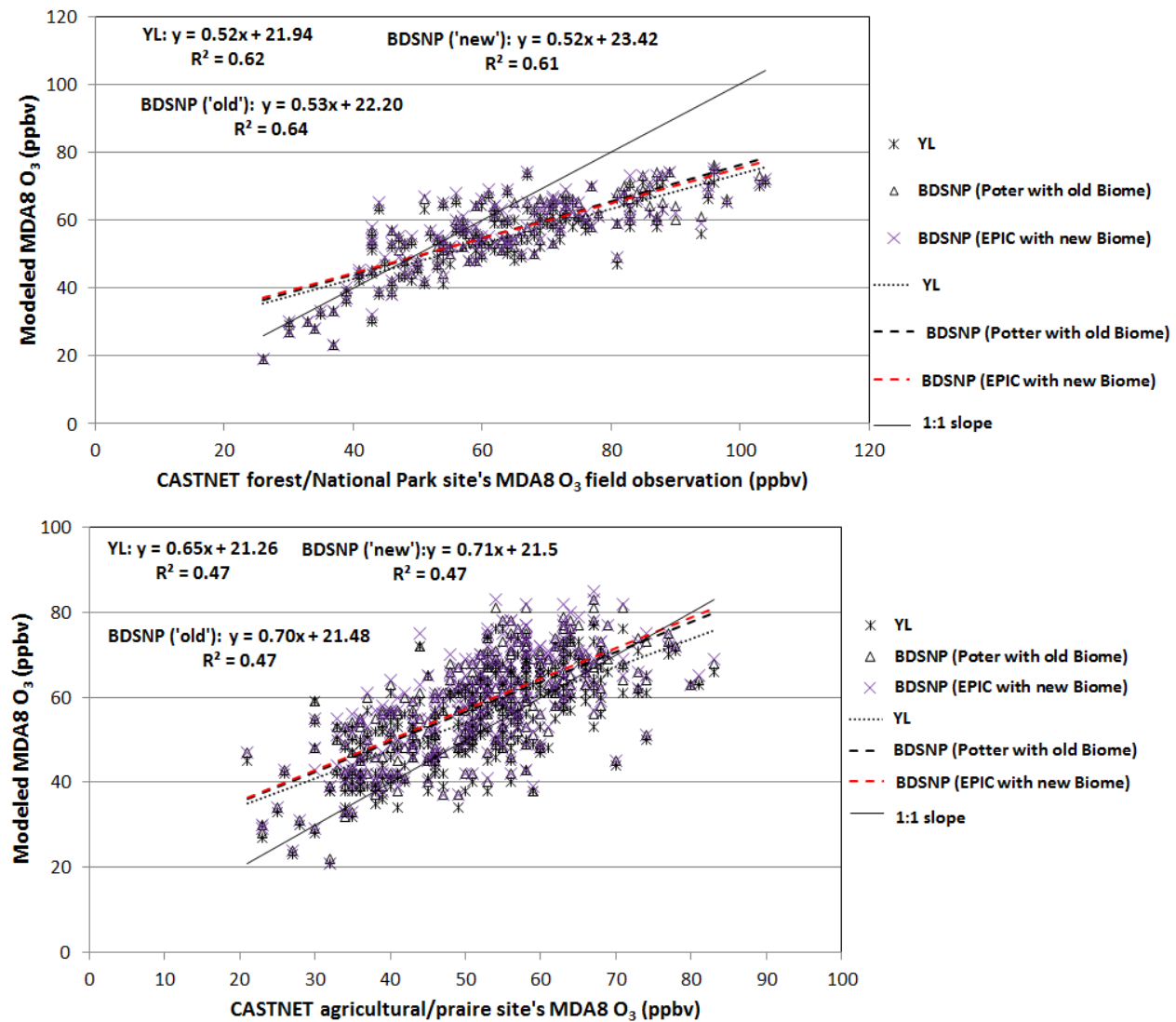

Figure 11. Comparison of the three in-line BDSNP-CMAQ cases with CASTNET MDA8 $\mathrm{O}_{3}$ data for forest/national park sites in California (top: number of evaluation sites, $n=147$ ) and agricultural/prairie sites in Midwest and southern USA (bottom: $n=311$ ) for July 2011.

\subsection{Impact of soil NO scheme on ozone sensitivity to anthropogenic $\mathrm{NO}_{x}$ perturbations}

We analyzed how the choice of soil NO parameterization affects the responsiveness of ozone to reductions in anthropogenic $\mathrm{NO}_{x}$ emissions. We applied emission perturbation factors based on the 5.7 million t reduction in baseline anthropogenic $\mathrm{NO}_{x}$ emissions from 2011 to 2025 that US EPA simulated in its latest RIA (US EPA, 2015). Table 4 gives the perturbation factors we used to obtain baseline anthropogenic $\mathrm{NO}_{x}$ emissions for 2025 over all contributing sectors as listed from NEI 2011. Since our simulation is for July 2011 over CONUS, we used these perturbation factors rather than the net reductions in RIA to scale emissions in a similar pattern as given in RIA for annual baseline perturbations from 2011 to 2025 with BAU.

Shifting from YL to the BDSNP soil NO scheme reduces the sensitivity of MDA8 $\mathrm{O}_{3}$ to anthropogenic $\mathrm{NO}_{x}$ perturbations. The impacts are the greatest in California and the Midwest, where shifting to BDSNP can reduce the expected impact of the anthropogenic $\mathrm{NO}_{x}$ reductions by $\sim 1$ to $1.5 \mathrm{ppbv}$. Changing the inputs within the BDSNP scheme has a smaller impact (Fig. 12). Our results imply that the higher soil NO
Table 4. Emission perturbation factors applied to anthropogenic $\mathrm{NO}_{x}$ emissions for each sector listed in NEI as per EPA's RIA base-line reductions from 2011 to 2025 with BAU (Table 2A-1; https://www3.epa.gov/ttn/ecas/docs/20151001ria.pdf).

\begin{tabular}{lr}
\hline Sectors (NEI file names) & $\begin{array}{r}\text { Perturbation } \\
\text { factor }\end{array}$ \\
\hline $\begin{array}{l}\text { Electric generating unit(EGU)-point } \\
\text { (ptimp-ptegu, ptegu_pk) }\end{array}$ & 0.70 \\
NonEGU-point (ptnonipm) & 1.00 \\
Point oil and gas (pt_oilgas) & 0.92 \\
Nonpoint oil and gas (np_oilgas) & 1.11 \\
Wild and prescribed fires & 1.00 \\
(ptwildfire, ptprescfire) & \\
Residential wood combustion (rwc) & 1.03 \\
Other nonpoint (nonpt) & 1.04 \\
Onroad (onroad) & 0.30 \\
Nonroad mobile equipment sources (nonroad) & 0.50 \\
Category 3 commercial marine vessel & 0.77 \\
(c3marine) & \\
Locomotive and category 1/category 2 & 0.62 \\
Commercial marine vessel (c1c2rail) & \\
\hline
\end{tabular}



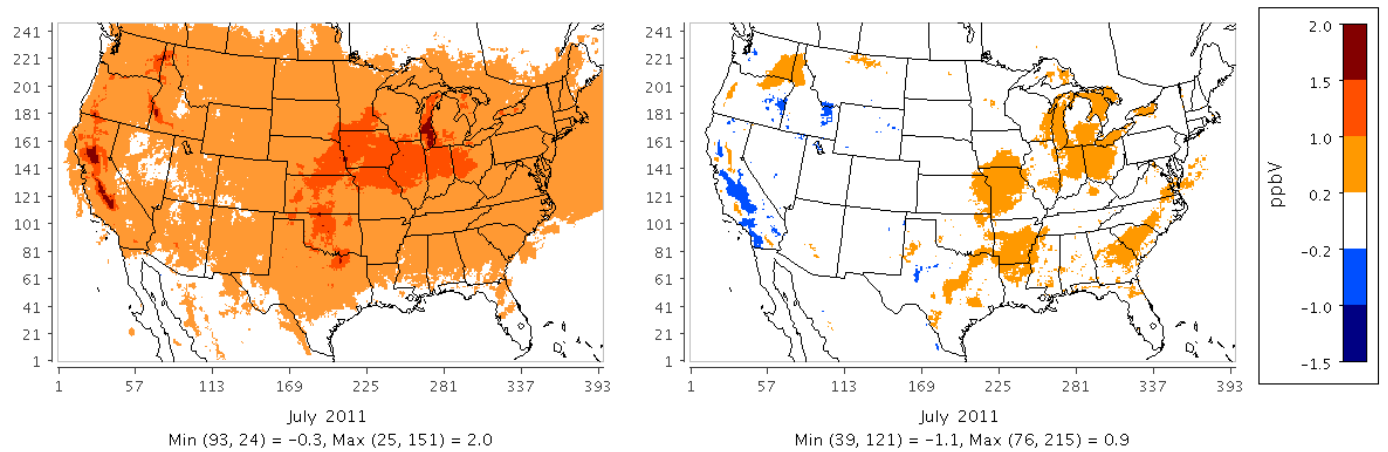

Figure 12. Difference in monthly mean MDA8 $\mathrm{O}_{3}$ perturbation between: (a) BDSNP (“old") - YL (left) and (b) BDSNP ("new") - BDSNP ("old") (right). MDA8 $\mathrm{O}_{3}$ perturbations are from perturbed anthropogenic $\mathrm{NO}_{x}$ estimates 2011 base case to 2025 base case, BAU (US EPA, 2015).

emissions from our updated BDSNP module shifts the ozone photochemistry to a less strongly $\mathrm{NO}_{x}$-limited regime.

\section{Conclusions}

Our BDSNP implementation represents a substantial update from the YL scheme for estimating soil NO in CMAQ. Compared to the previous implementation of BDSNP in global GEOS-Chem model, our implementation in CMAQ incorporated finer-scale representation of its dependence on land use, soil conditions, and $\mathrm{N}$ availability. This finer resolution and updated biome and fertilizer data set resulted in higher sensitivity of soil NO to biome emission factors. Our updated BDSNP scheme (EPIC and new biome) predicts slightly higher soil NO than the inputs used in GEOS-Chem, primarily due to the use of 2011 daily EPIC/FEST-C fertilizer data and fine resolution NLCD40 biomes (Fig. 6).

Sensitivities to different input data sets were examined using our offline BDSNP module to reduce computational cost. Switching from GEOS-Chem biome to new NLCD40 biome drops soil NO in the northwest and southwest portions of our domain due to the finer resolution biome map exhibiting lower emission factors in those regions. Replacing fertilizer data from Potter et al. (2010) with an EPIC 2011 data set increased soil NO mostly in the Midwest (Supplement Fig. S4).

We compared CMAQ tropospheric $\mathrm{NO}_{2}$ column densities to OMI observations as spatial averages, focusing on regions sensitive to the switch from YL to our updated BDSNP scheme. Temporal average of OMI and CMAQ simulated $\mathrm{NO}_{2}$ column densities was done over the OMI overpass time (13:00-14:00 local time) for the July 2011 monthly mean. Figure 7 summarizes tropospheric $\mathrm{NO}_{2}$ column density comparisons between model and OMI satellite observation for aforementioned sensitive regions. Central Texas showed improvement with a switch from YL to our BDSNP (new) scheme. For July 2011, central Texas and the San Joaquin Valley exhibit relatively dry soil conditions, whereas the Midwest was mostly wet (Supplement Fig. S5). Even with similar conditions as central Texas, the San Joaquin region shows overall degradation. Overestimation of simulated $\mathrm{NO}_{2}$ columns up to twice that of OMI over the Midwestern USA and San Joaquin Valley for summer episodes has been exhibited earlier as well (Lamsal et al., 2014). Several factors, such as spatial inhomogeneity within OMI pixels and possible errors arising from the stratosphere-troposphere separation scheme and air mass factor calculations, can be attributed to this overestimation. Retrieval difficulties in complex terrain may explain the discrepancies in the $\mathrm{NO}_{2}$ column over the San Joaquin Valley even though it shows slight improvement with updates within BDSNP (old to new) and has similar dry conditions as central Texas.

We examined the performance of CMAQ under each of the soil NO parameterizations. Regions where soil NO parameterizations most impacted MDA8 ozone and $\mathrm{PM}_{2.5}$ were examined for model performance in simulating CASTNET MDA8 $\mathrm{O}_{3}$ and IMPROVE $\mathrm{PM}_{2.5}$ observations.

For $\mathrm{PM}_{2.5}$, our updated BDSNP module (new) showed the best performance (Table 2). Evaluations against MDA8 $\mathrm{O}_{3}$ observations found contrasting behavior for two different sets of CASTNET sites. The 11 mostly agricultural and prairie sites extending across the Midwest and southern USA showed consistent overestimation as we moved from YL to BDNSP with new inputs, with bias jumping from $\sim 7$ to $14 \%$ and error from 15 to $19 \%$ (Table 3). However, the five forest/national park sites most of which lie near the San Joaquin Valley by contrast showed an overall improvement in bias from $\sim 13$ to $10 \%$ and in error from $\sim 17$ to $15 \%$ (Table 3 ).

Over-predictions of soil NO emissions especially in wet conditions may result from EPIC not properly accounting for on-farm nitrogen management practices like tile drainage. Crops such as alfalfa, hay, grass, and rice experience soil $\mathrm{N}$ loss due to tile drainage in wet soils (Gast et al., 1978; Randall et al., 1997). Recent updates to FEST-C (v. 1.2) include tile drainage for some crops but not hay, rice, grass, and alfalfa (CMAS, 2015). Tile drainage results in loss of fertilizer $\mathrm{N}$ to water run-off from wet or moist soils. 
We analyzed how the soil NO schemes affect the sensitivity of MDA8 ozone to anthropogenic $\mathrm{NO}_{x}$ reductions by considering the 5.7 million $\mathrm{yr}^{-1}$ reduction from 2011 levels that US EPA expects for USA by 2025 with BAU scenario. These reductions were applied on the basis of perturbation factors of relevant sectors keeping biogenic emissions unchanged for July 2011, based on EPA's annual baseline estimates between 2011 and 2025 (Table 4). These anthropogenic $\mathrm{NO}_{x}$ reductions yield less reduction in MDA8 $\mathrm{O}_{3}$ under the BDNSP soil NO scheme than YL, with 1-2 ppbv differences over parts of California and the Midwest (Fig. 12). The shift occurs because our updated BDSNP schemes have higher soil $\mathrm{NO}$ in these regions, pushing them toward less strongly $\mathrm{NO}_{x}$ limited regimes.

This work represents crucial advancement toward enhanced representation of soil NO in a regional model. Although possible wet biases and using dominant land cover rather than fractional in soil biome classification, may have over-predicted NO in agricultural regions in the present study. The EPIC simulation used here lacks complete representation of farming management practices like tile, which can reduced soil moisture and soil NO fluxes. Inclusion of biogeochemistry influencing different reactive $\mathrm{N}$ species encompassing the entire $\mathrm{N}$ cycling could enable more mechanistic representation of emissions. For future work, there is a need for more accurate representation of actual farming practices and internalizing updated soil reactive $\mathrm{N}$ biogeochemical schemes. More field observations are needed as well in order to increase the sample size for evaluation of modeled estimate soil emissions of reactive $\mathrm{N}$ species beyond NO.

\section{Code and data availability}

The modified and new scripts used for implementation of BDSNP in CMAQ version 5.0.2 are in the Supplement. Also provided as Supplement is the user manual giving details on implementing BDSNP module in-line with CMAQ, as used in this work. Source codes for CMAQ version 5.0.2 and FEST-C version 1.1 are both open source, available with applicable free registration at http://www.cmascenter.org. Advanced Research WRF model (ARW) version 3.6.1 used in this study is also available as a free open-source resource at http://www2.mmm.ucar.edu/wrf/users/download/ get_source.html. The model code, inputs, and sample outputs from this study have been uploaded to the Oak Ridge National Laboratory Distributed Active Archive Center for Biogeochemical Dynamics (http://daac.ornl.gov; Rasool et al., 2016). 


\section{Appendix A}

Table A1. List of 24 soil biome emission factors (EFs) from Steinkamp and Lawrence (2011).

\begin{tabular}{lllrrr}
\hline ID & MODIS land cover & $\begin{array}{l}\text { Köppen main } \\
\text { climate }^{*}\end{array}$ & $\begin{array}{r}\text { EF1 (world } \\
\text { geometric mean) }\end{array}$ & $\begin{array}{r}\text { EF2 (world } \\
\text { arithmetic mean) }\end{array}$ & $\begin{array}{r}\text { EF3 (North } \\
\text { American) }\end{array}$ \\
\hline 1 & Water & - & 0 & 0 & 0 \\
2 & Permanent wetland & - & 0 & 0 & 0 \\
3 & Snow and ice & - & 0 & 0 & 0 \\
4 & Barren & $\mathrm{D}, \mathrm{E}$ & 0 & 0 & 0 \\
5 & Unclassified & - & 0 & 0 & 0 \\
6 & Barren & $\mathrm{A}, \mathrm{B}, \mathrm{C}$ & 0.06 & 0.06 & 0.06 \\
7 & Closed shrubland & - & 0.09 & 0.21 & 0.05 \\
8 & Open shrubland & $\mathrm{A}, \mathrm{B}, \mathrm{C}$ & 0.09 & 0.21 & 0.09 \\
9 & Open shrubland & $\mathrm{D}, \mathrm{E}$ & 0.01 & 0.01 & 0.01 \\
10 & Grassland & $\mathrm{D}, \mathrm{E}$ & 0.84 & 1.05 & 0.62 \\
11 & Savannah & $\mathrm{D}, \mathrm{E}$ & 0.84 & 1.05 & 0.84 \\
12 & Savannah & $\mathrm{A}, \mathrm{B}, \mathrm{C}$ & 0.24 & 0.97 & 0.24 \\
13 & Grassland & $\mathrm{A}, \mathrm{B}, \mathrm{C}$ & 0.42 & 1.78 & 0.37 \\
14 & Woody savannah & - & 0.62 & 0.74 & 0.62 \\
15 & Mixed forest & - & 0.03 & 0.14 & 0.00 \\
16 & Evergreen broadleaf forest & $\mathrm{C}, \mathrm{D}, \mathrm{E}$ & 0.36 & 0.95 & 0.36 \\
17 & Deciduous broadleaf forest & $\mathrm{C}, \mathrm{D}, \mathrm{E}$ & 0.36 & 0.95 & 0.61 \\
18 & Deciduous needle forest & - & 0.35 & 0.95 & 0.35 \\
19 & Evergreen needle forest & - & 1.66 & 4.60 & 1.66 \\
20 & Deciduous broadl. forest & $\mathrm{A}, \mathrm{B}$ & 0.08 & 0.13 & 0.08 \\
21 & Evergreen broadl. forest & $\mathrm{A}, \mathrm{B}$ & 0.44 & 1.14 & 0.44 \\
22 & Cropland & - & 0.57 & 3.13 & 0.33 \\
23 & Urban and buildup lands & - & 0.57 & 0.13 & 0.57 \\
24 & Cropland/nat. veg. mosaic & - & 0.57 & & 0.57 \\
\hline
\end{tabular}

* A - equatorial, B - arid, C - warm temperature, D - snow, E - polar (see Fig. 2 for spatial map). 
Table A2. Mapping table to create the "new" soil biome map based on NLCD40 MODIS land cover categories.

\begin{tabular}{|c|c|c|c|}
\hline ID & NLCD40 MODIS category (40) & ID & Soil biome category (24) \\
\hline 1 & Evergreen needleleaf forest & 19 & Evergreen needleleaf forest \\
\hline 2 & Evergreen broadleaf forest & 16 and 21 & Evergreen broadleaf forest \\
\hline 3 & Deciduous needleleaf forest & 18 & Dec. needleleaf forest \\
\hline 4 & Deciduous broadleaf forest & 17 and 20 & Dec. broadleaf forest \\
\hline 5 & Mixed forests & 15 & Mixed forest \\
\hline 6 & Closed shrublands & 7 & Closed shrublands \\
\hline 7 & Open shrublands & 8 and 9 & Open shrublands \\
\hline 8 & Woody savannas & 14 & Woody savannah \\
\hline 9 & Savannas & 11 and 12 & Savannah \\
\hline 10 & Grasslands & 10 and 13 & Grassland \\
\hline 11 & Permanent wetlands & 2 & Permanent wetland \\
\hline 12 & Croplands & 22 & Cropland \\
\hline 13 & Urban and builtup & 23 & Urban and buildup lands \\
\hline 14 & Cropland-natural vegetation mosaic & 24 & Cropland-nat. veg. mosaic \\
\hline 15 & Permanent snow and ice & 3 & Snow and ice \\
\hline 16 & Barren or sparsely vegetated & 6 & Barren \\
\hline 17 & IGBP water & 1 & Water \\
\hline 18 & Unclassified & 1 & Water \\
\hline 19 & Fill value & 1 & Water \\
\hline 20 & Open water & 1 & Water \\
\hline 21 & Perennial ice and snow & 3 & Snow and ice \\
\hline 22 & Developed open space & 23 & Urban and buildup lands \\
\hline 23 & Developed low intensity & 23 & Urban and buildup lands \\
\hline 24 & Developed medium intensity & 23 & Urban and buildup lands \\
\hline 25 & Developed high intensity & 23 & Urban and buildup lands \\
\hline 26 & Barren land (rock-sand-clay) & 24 & Cropland/nat. veg. mosaic \\
\hline 27 & Unconsolidated shore & 24 & Cropland/nat. veg. mosaic \\
\hline 28 & Deciduous forest & 16 and 21 & Evergreen broadleaf forest \\
\hline 29 & Evergreen forest & 19 & Evergreen needle leaf forest \\
\hline 30 & Mixed forest & 15 & Mixed forest \\
\hline 31 & Dwarf scrub & 8 and 9 & Open shrublands \\
\hline 32 & Shrub-scrub & 8 and 9 & Open shrubland \\
\hline 33 & Grassland-herbaceous & 10 and 13 & Grassland \\
\hline 34 & Sedge-herbaceous & 14 & Woody savannah \\
\hline 35 & Lichens & 10 and 13 & Grassland \\
\hline 36 & Moss & 10 and 13 & Grassland \\
\hline 37 & Pasture-hay & 24 & Cropland-nat. veg. mosaic \\
\hline 38 & Cultivated crops & 22 & Cropland \\
\hline 39 & Woody wetlands & 2 & Permanent wetland \\
\hline 40 & Emergent herbaceous wetlands & 2 & Permanent wetland \\
\hline
\end{tabular}


Table A3. Summary of differences between YL, and the two applications of BDSNP. See Table 1 for other aspects of model configuration.

\begin{tabular}{|c|c|c|c|c|}
\hline & Features & YL & $\begin{array}{l}\text { BDSNP ( et al. (2010) with old } \\
\text { biome) }\end{array}$ & BDSNP (EPIC with new biome) \\
\hline (1) & $\begin{array}{l}\text { NO emission } \\
\text { response to biome, } \\
\text { temperature, and } \\
\text { moisture }\end{array}$ & $\begin{array}{l}\text { YL scheme uses a much generalized } \\
\text { biome classification by grouping } 36 \\
\text { NASA Global Vegetation Indexes to } 11 \\
\text { broad biome types. Ice, desert, and } \\
\text { snow } \\
\text { are attributed zero NO emission. The } \\
\text { rest of biomes use emission factors that } \\
\text { are empirical functions of soil tem- } \\
\text { perature behaving differently for dry } \\
\text { and wet soils. Linear variation with soil } \\
\text { temperature for dry soil, exponential } \\
\text { response to temperature for wet soils } \\
\text { (Yienger and Levy, 1995). }\end{array}$ & $\begin{array}{l}\text { Biome emission factors for } \\
40 \text { NLCD land use categories, } \\
\text { based on a coarse grid } \\
\text { definition from GEOS-Chem } \\
\text { LSM (Hudman et al., 2012). } \\
\text { Non-linear response to soil } \\
\text { temperature }(T) \text { and moisture } \\
(\theta) \text {. }\end{array}$ & $\begin{array}{l}\text { Biome emission factors regrouped } \\
\text { from } \\
\text { NLCD } 40 \text { to } 24 \text { MODIS land use types } \\
\text { (Steinkamp and Lawrence, 2011) with } \\
\text { Köppen climate definitions (Kottek et } \\
\text { al., 2006) to be consistent with finer } \\
\text { grid resolution used by Pleim-Xiu } \\
\text { LSM } \\
\text { in CMAQ. Non-linear response to soil } \\
T \text { and } \theta \text {. }\end{array}$ \\
\hline (2) & $\begin{array}{l}\text { NO emission } \\
\text { response to } \\
\text { deposition }\end{array}$ & $\begin{array}{l}\text { Deposition not accounted for as a } \\
\text { source of soil N. }\end{array}$ & $\begin{array}{l}\text { Deposition accounted for as a } \\
\text { soil N source, but separately } \\
\text { from fertilizer. }\end{array}$ & $\begin{array}{l}\text { Deposition accounted for as a soil } \mathrm{N} \\
\text { source. FEST-C soil N Deposition } \\
\text { (oxidized and reduced) outputs used, } \\
\text { also includes bi-directional exchange } \\
\text { capability of CMAQ, currently } \\
\text { implemented for } \mathrm{NH}_{3} \text { (reduced } \mathrm{N} \\
\text { depo- } \\
\text { sition source) only (Bash et al., 2013). }\end{array}$ \\
\hline (3) & $\begin{array}{l}\text { NO emission } \\
\text { response to } \\
\text { fertilizer }\end{array}$ & $\begin{array}{l}\text { Considers planting date and a decline } \\
\text { from NO fertilizer over the course of } \\
\text { the } \\
\text { growing season. }\end{array}$ & $\begin{array}{l}\text { Potter et al. (2010) long-term } \\
\text { average fertilizer estimates } \\
\text { used. }\end{array}$ & $\begin{array}{l}\text { Daily fertilizer estimates from EPIC/ } \\
\text { FEST-C, accounting for meteorology } \\
\text { and farm practices (Cooter et al., 2012). }\end{array}$ \\
\hline
\end{tabular}




\section{Appendix B}

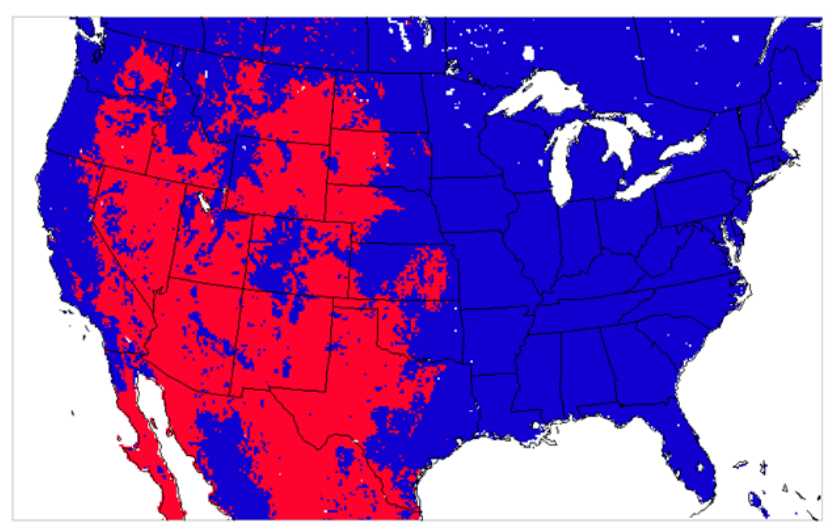

Figure B1. Arid (red) and non-arid (blue) region over continental USA (12 km resolution).

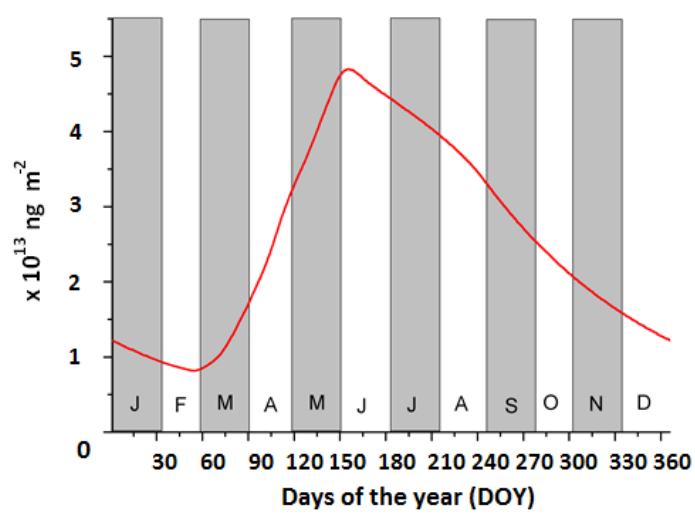

Figure B2. Daily variation of total $\mathrm{N}$ from fertilizer application (from Potter et al., 2010) processed from BDSNP to establish timing over continental USA throughout 2011.
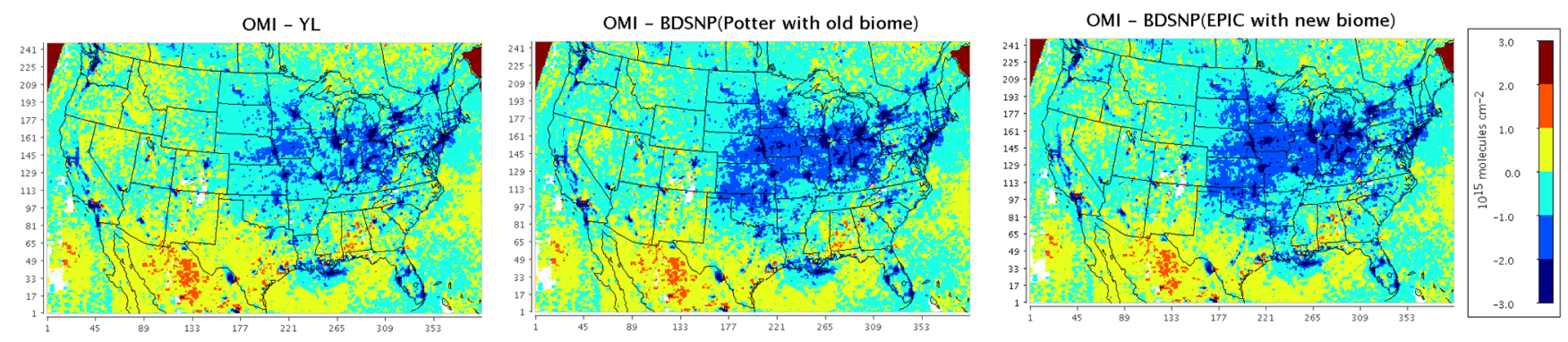

Figure B3. Difference of OMI NO 2 column with $\mathrm{NO}_{2}$ column simulated from the three in-line CMAQ cases: YL, BDSNP ( et al. (2010) with old biome), BDSNP (EPIC with new Biome) (left to right) over OMI overpass time averaged for July 2011 over CONUS. Note: in contour plots, white refers to gaps/no-fill values in OMI product and dark red at upper corners are due to gaps in $\mathrm{CMAQ} \mathrm{NO}_{2}$ column after temporal averaging at OMI overpass time. 


\section{The Supplement related to this article is available online at doi:10.5194/gmd-9-3177-2016-supplement.}

Disclaimer. Although this work was reviewed by EPA and approved for publication, it may not necessarily reflect official agency policy.

Acknowledgements. This work was supported by NASA's Air Quality Applied Sciences Team through a tiger team project grant for DYNAMO: DYnamic Inputs of Natural Conditions for Air Quality Models and by the Texas Air Quality Research Program.

Edited by: J. Williams

Reviewed by: K.-J. Liao and one anonymous referee

\section{References}

Bash, J. O., Cooter, E. J., Dennis, R. L., Walker, J. T., and Pleim, J. E.: Evaluation of a regional air-quality model with bidirectional $\mathrm{NH}_{3}$ exchange coupled to an agroecosystem model, Biogeosciences, 10, 1635-1645, doi:10.5194/bg-10-1635-2013, 2013.

Bey, I., Jacob, D. J., Yantosca, R. M., Logan, J. A., Field, B., Fiore, A. M., Li, Q., Liu, H., Mickley, L. J., and Schultz, M.: Global modeling of tropospheric chemistry with assimilated meteorology: Model description and evaluation, J. Geophys. Res., 106, 23073-23096, 2001.

Boersma, K., Jacob, D. J., Bucsela, E., Perring, A., Dirksen, R., Yantosca, R., Park, R., Wenig, M., Bertram, T., and Cohen, R.: Validation of OMI tropospheric $\mathrm{NO}_{2}$ observations during INTEX-B and application to constrain $\mathrm{NO}_{x}$ emissions over the eastern United States and Mexico, Atmos. Environ., 42, 44804497, 2008.

Bucsela, E. J., Krotkov, N. A., Celarier, E. A., Lamsal, L. N., Swartz, W. H., Bhartia, P. K., Boersma, K. F., Veefkind, J. P., Gleason, J. F., and Pickering, K. E.: A new stratospheric and tropospheric $\mathrm{NO}_{2}$ retrieval algorithm for nadir-viewing satellite instruments: applications to OMI, Atmos. Meas. Tech., 6, 26072626, doi:10.5194/amt-6-2607-2013, 2013.

Byun, D. W. and Schere, K. L.: Review of the governing equations, computational algorithms, and other components of the models 3 Community Multiscale Air Quality (CMAQ) modeling system, Appl. Mech. Rev., 59, 51-77, 2006.

Cheng, J.-L., Zhou, S., and Zhu, Y.-W.: Assessment and mapping of environmental quality in agricultural soils of Zhejiang Province, China, J. Environ. Sci., 19, 50-54, 2007.

CMAS: Sparse Matrix Operators Kernel Emissions model (SMOKE) version 3.6, University of North Carolina at Chapel Hill Institute for the Environment, Center for Environmental Modeling for Policy Development (CEMPD), Community Modeling and Analysis System Center (CMAS), Chapel Hill, NC, USA, available at: http://www.smoke-model.org (last access: 2 September 2016), 2014.
CMAS: User's Guide for the Fertilizer Emission Scenario Tool for CMAQ (FEST-C) Version 1.2, Institute of Environment, The University of North Carolina at Chapel Hill, Chapel Hill, NC, USA, available at: https://www.cmascenter.org/fest-c/ documentation/1.2/userManual.pdf (last access: 2 September 2016), 2015.

Conrad, R.: Soil microorganisms as controllers of atmospheric trace gases $\left(\mathrm{H}_{2}, \mathrm{CO}, \mathrm{CH}_{4}, \mathrm{OCS}, \mathrm{N}_{2} \mathrm{O}\right.$, and $\left.\mathrm{NO}\right)$, Microbiol. Rev., 60, 609-640, 1996.

Cooper, O. R., Parrish, D. D., Ziemke, J., Balashov, N. V., Cupeiro, M., Galbally, I. E., Gilge, S., Horowitz, L., Jensen, N. R., Lamarque, J. F., and Naik, V.: Global distribution and trends of tropospheric ozone: An observation-based review, Elementa: Science of the Anthropocene, 2, 000029, doi:10.12952/journal.elementa.000029, 2014.

Cooter, E. J., Bash, J. O., Walker, J. T., Jones, M. R., and Robarge, W.: Estimation of $\mathrm{NH}_{3}$ bi-directional flux from managed agricultural soils, Atmos. Environ., 44, 2107-2115. doi:10.1016/j.atmosenv.2010.02.044, 2010.

Cooter, E. J., Bash, J. O., Benson, V., and Ran, L.: Linking agricultural crop management and air quality models for regional to national-scale nitrogen assessments, Biogeosciences, 9, 40234035, doi:10.5194/bg-9-4023-2012, 2012.

Davidson, E.: Pulses of nitric oxide and nitrous oxide flux following wetting of dry soil: an assessment of probable sources and importance relative to annual fluxes, Ecol. Bull., 42, 149-155, 1992.

Davidson, E. and Kingerlee, W.: A global inventory of nitric oxide emissions from soils, Nutr. Cycl. Agroecosys., 48, 37-50, doi:10.1023/A:1009738715891, 1997.

Delon, C., Serça, D., Boissard, C., Dupont, R., Dutot, A., Laville, P., De Rosnay, P., and Delmas, R.: Soil NO emissions modelling using artificial neural network, Tellus B, 59, 502-513, 2007.

Delon, C., Reeves, C. E., Stewart, D. J., Serça, D., Dupont, R., Mari, C., Chaboureau, J.-P., and Tulet, P.: Biogenic nitrogen oxide emissions from soils - impact on $\mathrm{NO}_{x}$ and ozone over West Africa during AMMA (African Monsoon Multidisciplinary Experiment): modelling study, Atmos. Chem. Phys., 8, 2351-2363, doi:10.5194/acp-8-2351-2008, 2008.

Dinnes, D. L., Karlen, D. L., Jaynes, D. B., Kaspar, T. C., Hatfield, J. L., Colvin, T. S., and Cambardella, C. A.: Nitrogen management strategies to reduce nitrate leaching in tile-drained Midwestern soils, Agron. J., 94, 153-171, 2002.

Galloway, J. N. and Cowling, E. B.: Reactive nitrogen and the world: 200 years of change, AMBIO, 31, 64-71, 2002.

Gast, R., Nelson, W., and Randall, G.: Nitrate accumulation in soils and loss in tile drainage following nitrogen applications to continuous corn, J. Environ. Qual., 7, 258-261, 1978.

Harrison, R. M., Yamulki, S., Goulding, K., and Webster, C.: Effect of fertilizer application on $\mathrm{NO}$ and $\mathrm{N}_{2} \mathrm{O}$ fluxes from agricultural fields, J. Geophys. Res.-Atmos., 100, 25923-25931, 1995.

Hudman, R. C., Russell, A. R., Valin, L. C., and Cohen, R. C.: Interannual variability in soil nitric oxide emissions over the United States as viewed from space, Atmos. Chem. Phys., 10, $9943-$ 9952, doi:10.5194/acp-10-9943-2010, 2010.

Hudman, R. C., Moore, N. E., Mebust, A. K., Martin, R. V., Russell, A. R., Valin, L. C., and Cohen, R. C.: Steps towards a mechanistic model of global soil nitric oxide emissions: implementation and 
space based-constraints, Atmos. Chem. Phys., 12, 7779-7795, doi:10.5194/acp-12-7779-2012, 2012.

IFIA: Nitrogen, phosphate and potash statistics, International Fertilizer Industry Association 2001, available at: http://ifadata. fertilizer.org/ucSearch.aspx (last access: 6 September 2016), 2001.

IPCC: Climate Change 2007: Impacts, Adaptation and Vulnerability, Contribution of Working Group II to the Fourth Assessment Report of the Intergovernmental Panel on Climate Change, edited by: Parry, M. L., Canziani, O. F., Palutikof, J. P., van der Linden, P. J., and Hanson, C. E., Cambridge University Press, Cambridge, UK, 976 pp., 2007.

Jaeglé, L., Martin, R. V., Chance, K., Steinberger, L., Kurosu, T. P., Jacob, D. J., Modi, A. I., Yoboué, V., Sigha-Nkamdjou, L., and Galy-Lacaux, C.: Satellite mapping of rain-induced nitric oxide emissions from soils, J. Geophys. Res.-Atmos., 109, D21310, doi:10.1029/2004JD004787, 2004.

Jaeglé, L., Steinberger, L., Martin, R. V., and Chance, K.: Global partitioning of $\mathrm{NO}_{x}$ sources using satellite observations: Relative roles of fossil fuel combustion, biomass burning and soil emissions, Faraday Discuss., 130, 407-423, 2005.

Kesik, M., Blagodatsky, S., Papen, H., and Butterbach-Bahl, K.: Effect of $\mathrm{pH}$, temperature and substrate on $\mathrm{N}_{2} \mathrm{O}$, $\mathrm{NO}$ and $\mathrm{CO}_{2}$ production by Alcaligenes faecalis p., J. Appl. Microbiol., 101, 655-667, 2006.

Kottek, M., Grieser, J., Beck, C., Rudolf, B., and Rubel, F.: World Map of the Köppen-Geiger climate classification updated, Meteorol. Z., 15, 259-263, doi:10.1127/0941-2948/2006/0130, 2006.

Lamsal, L. N., Krotkov, N. A., Celarier, E. A., Swartz, W. H., Pickering, K. E., Bucsela, E. J., Gleason, J. F., Martin, R. V., Philip, S., Irie, H., Cede, A., Herman, J., Weinheimer, A., Szykman, J. J., and Knepp, T. N.: Evaluation of OMI operational standard $\mathrm{NO}_{2}$ column retrievals using in situ and surface-based $\mathrm{NO}_{2}$ observations, Atmos. Chem. Phys., 14, 11587-11609, doi:10.5194/acp14-11587-2014, 2014.

Li, Y., Schichtel, B. A., Walker, J. T., Schwede, D. B., Chen, X., Lehmann, C. M., Puchalski, M. A., Gay, D. A., and Collett, J. L.: Increasing importance of deposition of reduced nitrogen in the United States, P. Natl. Acad. Sci., 113, 5874-5879, doi:10.1073/pnas.1525736113, 2016.

Lin, J.-T.: Satellite constraint for emissions of nitrogen oxides from anthropogenic, lightning and soil sources over East China on a high-resolution grid, Atmos. Chem. Phys., 12, 2881-2898, doi:10.5194/acp-12-2881-2012, 2012.

Ludwig, J., Meixner, F., Vogel, B., and Förstner, J.: Soil-air exchange of nitric oxide: an overview of processes, environmental factors, and modeling studies, Biogeochemistry, 52, 225-257, doi:10.1023/A:1006424330555, 2001.

Malm, W. C., Sisler, J. F., Huffman, D., Eldred, R. A., and Cahill, T. A.: Spatial and seasonal trends in particle concentration and optical extinction in the United States, J. Geophys. Res., 99, 13471347, 1994.

Miyazaki, K., Eskes, H. J., and Sudo, K.: Global $\mathrm{NO}_{x}$ emission estimates derived from an assimilation of OMI tropospheric $\mathrm{NO}_{2}$ columns, Atmos. Chem. Phys., 12, 2263-2288, doi:10.5194/acp12-2263-2012, 2012.

Otte, T. L. and Pleim, J. E.: The Meteorology-Chemistry Interface Processor (MCIP) for the CMAQ modeling system: up- dates through MCIPv3.4.1, Geosci. Model Dev., 3, 243-256, doi:10.5194/gmd-3-243-2010, 2010.

Parton, W. J., Holland, E. A., Del Grosso, S. J., Hartman, M. D., Martin, R. E., Mosier, A. R., Ojima, D. S., and Schimel, D. S.: Generalized model for $\mathrm{NO}_{x}$ and $\mathrm{N}_{2} \mathrm{O}$ emissions from soils, J. Geophys. Res.-Atmos., 106, 17403-17419, doi:10.1029/2001JD900101, 2001.

Pilegaard, K.: Processes regulating nitric oxide emissions from soils, Philos. T. Roy. Soc. B, 368, 20130126, doi:10.1098/rstb.2013.0126, 2013.

Pleim, J. E. and Xiu, A.: Development of a land surface model. Part II: Data assimilation, J. Appl. Meteorol., 42, 1811-1822, 2003.

Potter, C., Matson, P., Vitousek, P., and Davidson, E.: Process modeling of controls on nitrogen trace gas emissions from soils worldwide, J. Geophys. Res.-Atmos., 101, 1361-1377, doi:10.1029/95JD02028, 1996.

Potter, P., Navin, R., Elena, M. B., and Simon, D. D.: Characterizing the spatial patterns of global fertilizer application and manure production, Earth Interact., 14, 1-22, 2010.

Randall, G., Huggins, D., Russelle, M., Fuchs, D., Nelson, W., and Anderson, J.: Nitrate losses through subsurface tile drainage in conservation reserve program, alfalfa, and row crop systems, J. Environ. Qual., 26, 1240-1247, 1997.

Rasool, Q. Z., Zhang, R., Cohan, D. S., Cooter, E. J., Lamsal, L. N., Bash, J. O., and Lash, B.: BDSNP module in-line in CMAQ model Data Repository, Oak Ridge National Laboratory Distributed Active Archive Center for Biogeochemical Dynamics, available at: http://daac.ornl.gov, last access: 13 September 2016.

Scholes, M., Martin, R., Scholes, R., Parsons, D., and Winstead, E.: $\mathrm{NO}$ and $\mathrm{N}_{2} \mathrm{O}$ emissions from savanna soils following the first simulated rains of the season, Nutr. Cycl. Agroecosys., 48, 115122, doi:10.1023/A:1009781420199, 1997.

Seinfeld, J. H. and Pandis, S. N.: Atmospheric chemistry and physics: from air pollution to climate change, 3rd edition, John Wiley \& Sons, Hoboken, New Jersey, USA, 2016.

Shepherd, M., Barzetti, S., and Hastie, D.: The production of atmospheric $\mathrm{NO}_{x}$ and $\mathrm{N}_{2} \mathrm{O}$ from a fertilized agricultural soil, Atmos. Environ. A-Gen., 25, 1961-1969, 1991.

Skamarock, W. C., Klemp, J. B., Dudhia, J., Gill, D. O., Barker, D. M., Duda, M. G., Huang, X., Wang, W., and Powers, J. G.: A description of the advanced research WRF version 3, NCAR Tech. Note, NCAR/TN-475+STR, 8 pp., Natl. Cent. for Atmos. Res., Boulder, CO, USA, available at: http://www2.mmm.ucar. edu/wrf/users/docs/arw_v3.pdf (last access: 2 September 2016), 2008.

Stavrakou, T., Müller, J.-F., Boersma, K. F., De Smedt, I., and van der A, R. J.: Assessing the distribution and growth rates of $\mathrm{NO}_{x}$ emission sources by inverting a 10 year record of NO2 satellite columns, Geophys. Res. Lett., 35, L10801, doi:10.1029/2008GL033521, 2008.

Stavrakou, T., Müller, J.-F., Boersma, K. F., van der A, R. J., Kurokawa, J., Ohara, T., and Zhang, Q.: Key chemical $\mathrm{NO}_{x}$ sink uncertainties and how they influence top-down emissions of nitrogen oxides, Atmos. Chem. Phys., 13, 9057-9082, doi:10.5194/acp-13-9057-2013, 2013.

Stehfest, E. and Bouwman, L.: $\mathrm{N}_{2} \mathrm{O}$ and $\mathrm{NO}$ emission from agricultural fields and soils under natural vegetation: summarizing available measurement data and modeling of global annual emissions, 
Nutr. Cycl. Agroecosys., 74, 207-228, doi:10.1007/s10705-0069000-7, 2006.

Steinkamp, J. and Lawrence, M. G.: Improvement and evaluation of simulated global biogenic soil NO emissions in an AC-GCM, Atmos. Chem. Phys., 11, 6063-6082, doi:10.5194/acp-11-60632011, 2011.

Strode, S. A., Rodriguez, J. M., Logan, J. A., Cooper, O. R., Witte, J. C., Lamsal, L. N., Damon, M., Van Aartsen, B., Steenrod, S. D., and Strahan, S. E.: Trends and variability in surface ozone over the United States, J. Geophys. Res.-Atmos., 120, 9020-9042, doi:10.1002/2014JD022784, 2015.

Su, H., Cheng, Y., Oswald, R., Behrendt, T., Trebs, I., Meixner, F. X., Andreae, M. O., Cheng, P., Zhang, Y., and Pöschl, U.: Soil nitrite as a source of atmospheric $\mathrm{HONO}$ and $\mathrm{OH}$ radicals, Science, 333, 1616-1618, 2011.

USDA ERS: USDA ERS (United States Department of Agriculture, Economic Research Service) Data sets: U.S. fertilizer use and price, last updated 12 July 2013, available at: http://www.ers. usda.gov/data-products/fertilizer-use-and-price.aspx (last access: 2 September 2016), 2013.

U.S. EPA: Regulatory Impact Analysis of the Final Revisions to the National Ambient Air Quality Standards for GroundLevel Ozone, EPA-452/R-15-007, U.S. Environmental Protection Agency, 2015, Office of Air Quality Planning and Standards, Research Triangle Park, NC, USA, last updated: March 2016, available at: https://www3.epa.gov/ttn/ecas/docs/20151001ria. pdf (last access: 2 September 2016), 2015.

van Dijk, S. M., Gut, A., Kirkman, G. A., Gomes, B. M., Meixner, F. X., and Andreae, M. O.: Biogenic NO emissions from forest and pasture soils: Relating laboratory studies to field measurements, J. Geophys. Res., 107, 8058, doi:10.1029/2001JD000358, 2002.

Veldkamp, E. and Keller, M.: Fertilizer-induced nitric oxide emissions from agricultural soils, Nutr. Cycl.Agroecosys., 48, 69-77, 1997.

Vinken, G. C. M., Boersma, K. F., Maasakkers, J. D., Adon, M., and Martin, R. V.: Worldwide biogenic soil $\mathrm{NO}_{x}$ emissions inferred from $\mathrm{OMI} \mathrm{NO} 2$ observations, Atmos. Chem. Phys., 14, 1036310381, doi:10.5194/acp-14-10363-2014, 2014.
Wang, Y., Logan, J. A., and Jacob, D. J.: Global simulation of tropospheric $\mathrm{O}_{3}-\mathrm{NO}_{x}$-hydrocarbon chemistry: 2. Model evaluation and global ozone budget, J. Geophys. Res.-Atmos., 103, 1072710755, 1998.

Wang, Y., McElroy, M. B., Martin, R. V., Streets, D. G., Zhang, Q., and $\mathrm{Fu}, \mathrm{T}$. M.: Seasonal variability of $\mathrm{NO}_{x}$ emissions over east China constrained by satellite observations: Implications for combustion and microbial sources, J. Geophys. Res.-Atmos., 112, D06301, doi:10.1029/2006JD007538, 2007.

Wang, Y., Zhang, Q. Q., He, K., Zhang, Q., and Chai, L.: Sulfatenitrate-ammonium aerosols over China: response to 2000-2015 emission changes of sulfur dioxide, nitrogen oxides, and ammonia, Atmos. Chem. Phys., 13, 2635-2652, doi:10.5194/acp-132635-2013, 2013.

Williams, E. J., Parrish, D. D., Buhr, M. P., Fehsenfeld, F. C., and Fall, R.: Measurement of soil $\mathrm{NO}_{x}$ emissions in central Pennsylvania, J. Geophys. Res.-Atmos., 93, 9539-9546, doi:10.1029/JD093iD08p09539, 1988.

Williams, E. J., Guenther, A., and Fehsenfeld, F. C.: An inventory of nitric oxide emissions from soils in the United States, J. Geophys. Res., 97, 7511-7519, 1992.

Yienger, J. and Levy, H.: Empirical model of global soil-biogenic $\mathrm{NO}_{x}$ emissions, J. Geophys. Res., 100, 11447-11464, 1995.

Zhang, W., Mo, J., Yu, G., Fang, Y., Li, D., Lu, X., and Wang, H.: Emissions of nitrous oxide from three tropical forests in Southern China in response to simulated nitrogen deposition, Plant Soil, 306, 221-236, 2008.

Zhao, C. and Wang, Y.: Assimilated inversion of $\mathrm{NO}_{x}$ emissions over East Asia using $\mathrm{OMI} \mathrm{NO}_{2}$ column measurements, Geophys. Res. Lett., 36, L06805, doi:10.1029/2008GL037123, 2009.

Zörner, J., Penning de Vries, M., Beirle, S., Sihler, H., Veres, P. R., Williams, J., and Wagner, T.: Multi-satellite sensor study on precipitation-induced emission pulses of $\mathrm{NO}_{x}$ from soils in semi-arid ecosystems, Atmos. Chem. Phys., 16, 9457-9487, doi:10.5194/acp-16-9457-2016, 2016. 